\title{
The Evolution of Gene Therapy in the Treatment of Metabolic Liver Diseases
}

\author{
Carlos G. Moscoso ${ }^{1, *(1)}$ and Clifford J. Steer ${ }^{1,2, *}$ \\ 1 Department of Medicine, Division of Gastroenterology, Hepatology and Nutrition, University of Minnesota \\ Medical School, Minneapolis, MN 55455, USA \\ 2 Department of Genetics, Cell Biology and Development, University of Minnesota Medical School, \\ Minneapolis, MN 55455, USA \\ * Correspondence: cmoscoso@umn.edu (C.G.M.); steer001@umn.edu (C.J.S.); \\ Tel.: +1-612-625-8999 (C.G.M. \& C.J.S.); Fax: +1-612-625-5620 (C.G.M. \& C.J.S.)
}

Received: 18 May 2020; Accepted: 6 August 2020; Published: 10 August 2020

\begin{abstract}
Monogenic metabolic disorders of hepatic origin number in the hundreds, and for many, liver transplantation remains the only cure. Liver-targeted gene therapy is an attractive treatment modality for many of these conditions, and there have been significant advances at both the preclinical and clinical stages. Viral vectors, including retroviruses, lentiviruses, adenovirus-based vectors, adeno-associated viruses and simian virus 40 , have differing safety, efficacy and immunogenic profiles, and several of these have been used in clinical trials with variable success. In this review, we profile viral vectors and non-viral vectors, together with various payloads, including emerging therapies based on RNA, that are entering clinical trials. Genome editing technologies are explored, from earlier to more recent novel approaches that are more efficient, specific and safe in reaching their target sites. The various curative approaches for the multitude of monogenic hepatic metabolic disorders currently at the clinical development stage portend a favorable outlook for this class of genetic disorders.
\end{abstract}

Keywords: genome editing; liver-targeted gene therapy; CRISPR/Cas9; TALENs; zinc finger nucleases; viral vectors

\section{Introduction}

The liver is the principal organ in the body involved in the metabolism and detoxification of numerous agents; and multiple disorders of metabolism are of hepatic origin. There are as many as 400 inherited and acquired metabolic disorders caused by a single gene mutation, and for many of these, orthotopic liver transplantation is the only known curative therapy. Liver-targeted gene therapy (LTGT) has been successfully applied in preclinical models of various disorders, including hemophilia A and B, urea cycle disorders and familial hypercholesterolemia, with varying degrees of success. Given the monogenic nature of many of these disorders, a gene therapy approach appears naturally suited for therapeutic benefit. Viral vector-based approaches have overcome significant hurdles, with progress made on inherent viral protein immunogenicity, toxicity, specificity of target site delivery and methods of delivery. In addition, non-viral approaches, including genome editing, have made significant advances in improving the safety and efficacy profile of these novel technologies to gene therapy. In conclusion, we present in this review the evolution and current status of the various technologies available for LTGT as well as the challenges that still exist. 


\section{Viral Vectors}

\subsection{Retroviral and Lentiviral Vectors}

As their name implies, retroviruses reverse-transcribe their RNA genome into DNA, which subsequently forms part of the pre-integration nucleoprotein complex. Retrovirus-based vectors, based principally on murine leukemia virus (MLV), have been used in multiple clinical trials of gene therapy (Figure 1A). Retroviral vectors with modified and pseudotyped envelope proteins have been engineered to selectively target different cell types, including hepatocytes [1-4]. Since hepatocytes are largely quiescent and do not replicate frequently in vivo, the use of retroviruses in LTGT is largely limited to lentiviruses, given that MLV pre-integration nucleosome complexes are unable to cross the nuclear membrane [5]. Notwithstanding this limitation, an in vivo murine study showed stable correction of hemophilia A via retroviral expression of human factor VIII [6]. However, the development of leukemia following the clinical use of retroviral vectors in ex vivo hematopoietic stem cell therapy for severe combined immunodeficiency disorder [7] exemplified the insertional oncogenic risk associated with retroviral vectors.

Lentiviral vectors are derived from HIV and have been well characterized in the literature for their ability to transduce quiescent cells [8]. LTGT is an attractive application compared to retroviruses given their improved stability [9], ability to transduce quiescent cells [10,11], improved titers [12] and reduced frequency of insertional mutagenesis [13-15]. While lentiviral vectors are often pseudotyped with vesicular stomatitis virus glycoprotein (VSV-G) for preclinical studies $[16,17]$, the finding that human complement inactivates these vectors and lowers their transduction efficacy [18] has resulted in the use of complement-resistant vesiculovirus strains for pseudotyping [19]. Integration of the human phagocytosis inhibitor CD47 into lentiviral particles via budding in cell lines overexpressing CD47 resulted in improved gene transfer, enhanced hepato- and splenoselectivity, and reduced insertional mutagenesis. This allowed the use of lower doses of lentiviral administration to achieve supraphysiologic factor IX levels in a nonhuman primate model of hemophilia B [20]. Integrase-defective lentiviral vectors resulted in sustained transgene expression, and the prevention of the induction of neutralizing antibodies against factor IX was observed even after re-challenge in a murine model of hemophilia B [21]. HBV (hepatitis B virus) replication was inhibited using CRISPR/Cas9 (clustered regularly interspaced palindromic repeats/CRISPR-associated protein 9) via lentiviral transduction in vivo and in vitro [22,23]. A Phase I trial is currently underway for hemophilia $\mathrm{B}$, using patient stem cells, the ex vivo gene correction of factor IX using an advanced lentiviral vector and autologous gene therapy (ClinicalTrials.gov identifier NCT03961243). The incorporation of protective elements to improve lentiviral transduction and transgene expression, such as CD47 and integrase-defective variants, are important advances that render lentiviral vectors more attractive for future gene therapy clinical trials.

\subsection{Adenoviral Vectors}

Adenoviruses are enveloped double-stranded DNA viruses capable of infecting both quiescent and dividing cells (Figure 1B). There are concerns with the persistence of gene expression following LTGT using adenoviral vectors, given that as much as $95 \%$ of gene expression is lost over the course of one year in murine models [24]. Though it has been shown that the mechanism for the loss of gene expression is not solely due to cellular division [25], the exact mechanisms for both residual expression and reactivation are poorly understood. A rat model of Crigler-Najjar syndrome was used to correct hyperbilirubinemia via the hepatic delivery of an adenoviral vector encoding uridine diphosphate glucuronosyltransferase isoform 1A1 (UGT1A1), the enzyme that conjugates bilirubin [26]. In a rat model of estrogen-induced cholestasis, the human aquaporin 1 gene was delivered via an adenoviral vector and resulted in a lower serum concentration of bile salts and improved biliary output [27]. Transgenic mice with a deletion of miR-221/222 were experimentally challenged to develop non-alcoholic steatohepatitis (NASH). Reintroduction of miR-221/222 via an adenoviral vector 
controlled the expression of target gene Timp3 and promoted the progression of NASH in a murine model [28].

Adenoviral vectors are beset by widely prevalent pre-existing immunity, which can limit the effectiveness of adenovirus-based vaccines and gene therapy [29,30]. Specifically, adenovirus-specific $\mathrm{CD}^{+} \mathrm{T}$ lymphocyte-mediated cytotoxicity against adenovirus-infected cells caused cell lysis and the loss of transgene, reducing the efficacy of expression [31]. This risk has been attenuated by the engineering of "gutless" rAd vectors, termed helper-dependent adenovirus (HDAd), with some moderate success in vivo [32]. The small size of the early region 1 genes (E1) limits the size of the transgene that can be used in first-generation adenoviral vectors, as E1 is replaced by the transgene. HDAd vectors circumvent this problem by removing all viral genes from the vector, leaving only cis-acting elements needed for vector genome replication and encapsidation, and freeing up to $37 \mathrm{~kb}$ of space for large transgenes [33]. HDAd vectors elicited minimal cytotoxic T lymphocyte responses due to a lack of expression of viral proteins in transduced cells [34]. They are, as their name suggests, dependent on a helper adenovirus for propagation given the lack of expression of viral proteins needed to replicate and to package the HDAd vector. The adenovirus genome mostly does not integrate and remains episomal, with integration being reported at low frequency [35] and, thus, there is minimal risk of insertional mutagenesis [36]. The long-term expression of transgenes has been reported in animals $[37,38]$. This system has been successfully used in LTGT. Co-transduction of HDAd with Sleeping Beauty transposons in a canine hemophilia B model resulted in the stable expression of factor IX for nearly 1000 days $[39,40]$. In a mouse model of primary hyperoxaluria 1 (PH1), the increased stable expression of alanine:glyoxylate aminotransferase (AGT) and decreased hyperoxaluria were observed, thus establishing the long-term correction of PH1 [41]. The use of HDAd vectors in a nonhuman primate model of $\alpha-1$ antitrypsin (AAT) deficiency resulted in the stable expression of AAT [32]. There have not yet been any successful clinical applications using HDAd vectors and contamination with immunogenic helper adenovirus can lead to acute genotoxicity and the induction of severe immune responses in the host, raising concerns about the safety of this approach.

\subsection{Adeno-Associated Viral Vectors}

The adeno-associated virus (AAV) is a single-stranded DNA, non-enveloped, replication-defective virus (Figure 1C) [42]. Productive infection with a lytic phase only occurs in the presence of a helper virus, canonically either herpesvirus or adenovirus, with complex interactions and contributions to the AAV life cycle. In the absence of a helper virus, there is limited replication and viral gene expression. AAV serotype 2 (AAV2) has been shown to integrate specifically in chromosome 19q13.4 (the AAVS1 locus) [43] and establish latency in the presence of Rep viral proteins and via interaction with inverted terminal repeats. In humans, up to $90 \%$ of the population has been exposed to AAV2, and thus recombinant AAV (rAAV) vectors are safer and the most frequently used viral vectors for LTGT. A significant proportion of exposed humans develop neutralizing antibodies against AAV, with high cross-reactivity between serotypes, which impacts the utility of AAV vectors [44]. Indeed, in one AAV clinical trial, all subjects developed neutralizing antibodies against the vector capsid [45]. As such, the detection of neutralizing antibodies is important prior to preclinical and clinical studies, as is the monitoring of humoral and cellular responses following administration. Up to $96 \%$ of the AAV genome can be replaced with transgenic DNA and while AAV2 is the most widely used serotype, other serotypes have been shown to have differential tropism and transduction efficiency [46]. For example, serotype 3 (AAV3) has been identified as a promising serotype for transduction in human hepatocytes and hepatocellular carcinoma (HCC) cells [47,48]. AAV expression is primarily episomal (extrachromosomal) in nature [48]. While this may suggest that AAV would have suboptimal transduction efficiency in dividing cells, various serotypes have been shown to transduce dividing and non-dividing cells. Specifically, AAV2, AAV3 and AAV6 are able to transduce HEK293, HeLa, HBEC and Saos-2 cell lines efficiently [46]. A mouse study of hemophilia B found that the expression of factor 
IX administered via an $\mathrm{rAAV}$ vector decreased by $92 \%$ following two-thirds hepatectomy, suggesting limited expression of the episomal transgene with cell replication [48].

Chimeric AAV vectors have been recombinantly engineered to combine favorable qualities of various AAV serotypes. For example, the AAV-DJ recombinant vector is a chimera derived from serotypes 2, 8 and 9 via a DNA family shuffling approach [49]. AAV-DJ was superior to eight standard AAV serotypes for in vitro transduction, mediated robust human factor IX expression in mice and a heparin-binding domain limited distribution of this vector largely to the liver. More recently, a chimera comprising seven different AAV serotypes $(1,2,3 B, 4,6,8$ and 9) was engineered, which preferentially transduced human hepatocytes at higher efficiencies than rAAV8, rAAV3B and rAAV-DJ [50].

Notwithstanding the transduction efficiency seen with rAAV vectors, there are concerns regarding oncogenic integration. A particularly oncogenic site was identified in mice in a 6 kilobase region on chromosome 12 encoding various small nucleolar RNAs and microRNAs [51]. In humans, AAV2 clonal integration in known cancer driver genes was identified in various samples of human HCC [52]. For example, AAV2 was found to be integrated in the TERT promoter, which encodes telomerase reverse transcriptase, as well as in other genes in 11 of 193 HCCs analyzed. However, these findings were challenged on multiple bases by several groups [53,54], underscoring the uncertainty surrounding the potential for the insertional oncogenicity of AAV. In a Korean cohort, AAV-associated HCC was found to be very rare [55]; however, a recent genomic analysis of frozen hepatic parenchyma from 936 patients again demonstrated a correlation between AAV oncogenic insertion and the incidence of HCC in non-cirrhotic liver [56]. These results demonstrated a significant, albeit infrequent, risk of AAV-related insertional oncogenicity, although its significance as compared to wild-type exposure remains in question [57].

There have been various successful in vitro and in vivo applications of LTGT using AAV vectors. A murine model of Wilson's disease demonstrated that a single injection of rAAV8, containing complementary DNA encoding copper transporting ATPase 2, normalized serum holoceruloplasmin levels and hepatic parenchymal copper levels for more than 6 months after administration [58]. Persistent expression of human porphobilinogen in a mouse model of acute intermittent porphyria reduced the frequency of biochemical attacks and the degree of neuropathy [59,60]. Intravenous delivery of propionyl-CoA carboxylase subunits via AAV8 decreased serum levels of toxins found in a murine model of propionyl acidemia [61]. Methylmalonic acidemia was corrected via the delivery of cDNA with an rAAV8 vector in a mouse model, preventing neonatal lethality [62]. In a murine model of phenylketonuria, the delivery of phenylalanine hydroxylase via an rAAV8 vector reduced serum phenylalanine levels [63]. In animal models of glycogen storage disease type Ia, with hypoglycemia, increased hepatic glycogen and hepatic steatosis, the rAAV8 delivery of glucose-6-phosphatase (G6P) resulted in the stable expression of G6P and a correction of the various defects in mice and canines $[64,65]$. An AAV8 vector was used to deliver ATP binding cassette subfamily $B$ member 4 (ABCB4) in a murine model of progressive familial intrahepatic cholestasis 3, leading to stable ABCB4 expression and the amelioration of the progression of liver fibrosis [66]. A canine study of hemophilia A, using AAV8 or AAV9 to deliver canine factor VIII resulted in the stable expression of factor VIII and a reduction in bleeding episodes [67]. It was observed that transgene expression unexpectedly declined after one year. A 10-year follow up study revealed stable expression of factor VIII with AAV genome integration and clonal expansion, but with no evidence of tumorigenesis or other adverse effects [68]. These animal studies emphasize the versatility of AAV vectors.

Given the safety, stability, lack of pathogenicity and low immunogenicity of AAV vectors, various clinical trials using rAAV vectors are underway. A clinical study in six patients with severe hemophilia $B$ demonstrated that a peripherally administered AAV vector expressing human factor IX resulted in stable expression at $2-11 \%$ of normal levels, which was sufficient to ameliorate the bleeding diathesis [69]. Higher expression levels have been achieved more recently. As examples, a trial of hemophilia A using an AAV5 vector resulted in activity levels ranging from 19\% to $164 \%$ one year after administration [45], and the use of a high-specific-activity factor IX variant resulted in expression 
levels ranging from $14 \%$ to $81 \%$ [70]. A three-year follow-up study revealed that two of the 15 patients in that trial had negligible expression of factor VIII, while others had sufficient expression and required minimal use of exogenous factor VIII [71]. While transgene expression may not be a permanent cure, the results are nonetheless encouraging.

A Phase I clinical trial for acute intermittent porphyria, using an rAAV2 vector delivering porphobilinogen deaminase, demonstrated safety but not metabolic correction at the doses tested, though varied outcomes were noted. Interestingly, two of eight patients were able to discontinue hematin treatment [72]. A Phase I/II clinical trial for homozygous familial hypercholesterolemia is currently underway (NCT02651675). Promising AAV-delivered agents currently in Phase III trials include AMT-061, a Padua variant Factor IX for hemophilia B (NCT03569891); fidanacogene elaparvovec, a high-activity factor IX gene for hemophilia B (NCT03587116); GS010, encoding the human wild-type ND4 protein for Leber hereditary optic neuropathy (NCT02652780, NCT02652767, NCT03293524); LYS-SAF302, encoding N-sulfoglucosamine sulfohydrolase for the treatment of mucopolysaccharidosis IIIA (NCT03612869); NSR-REP1, encoding REP1 for the treatment of choroideremia (NCT03496012); and valoctocogene roxaparvovec, encoding factor VIII for hemophilia A (NCT03370913; NCT03392974). Two AAV-based gene therapies that were recently approved by the FDA include Luxturna (voretigene neparvovec-rzyl) for the treatment of biallelic RPE65 mutation-associated retinal dystrophy [73] and Zolgensma (onasemnogene abeparvovec-xioi) for the treatment of spinal muscular atrophy [74].

These encouraging results showcase the promise of AAV vectors in LTGT, though the immunogenicity, oncogenicity, host AAV immunity and permanence of these vectors in humans remains a source of intense research. Indeed, the development of neutralizing antibodies against AAV vectors has been observed in clinical trials and has been correlated with a decrease in transduction efficacy [75-79], though this is not likely the main cause of the loss of transgene expression. The development of chimeric AAV vectors with increased cell type specificity and efficacy of transduction portends well for future clinical applications.

\subsection{Simian Virus 40}

Simian virus 40 (SV40) is a double-stranded DNA virus encoding two viral antigens, large (Tag) and small (tag) $\mathrm{T}$ cell antigens, as well as three structural proteins, VP1, VP2 and VP3 (Figure 1D) [80]. Recombinant SV40 (rSV40) has a transgene in place of the Tag gene, rendering it replication incompetent and much less immunogenic than wild-type SV40. A murine study of partially resected and regenerated liver showed that, when rSV40 was used to transduce mouse liver, transgene expression was comparable prior to resection and after regeneration. The results indicated that despite their replication incompetence, rSV40 vectors persist despite considerable cellular divisions and are highly stable [81]. In a murine model of Crigler-Najjar syndrome type I, intravenous administration of rSV40 encoding UGT1A1 resulted in stable expression of the transgene, normalization of alanine aminotransferase and bilirubin serum levels and normal liver histology [82]. However, ongoing concerns over its safety, due to the production of infectious wild-type SV40 particles in replication-defective SV40 packaging cell lines [83], have slowed the transition of this vector from preclinical research to clinical applications. More importantly, it has been observed that primary cell lines are immortalized in the presence of both large and small $\mathrm{T}$ antigens, that established cell lines are readily transformed and that tumors are induced in immunocompromised hamsters, events that do not transpire with the expression of individual T antigens [84]. Given these observations and the risk of vector-induced oncogenicity, there has been an effort to develop packaging cell lines with enhanced safety profiles. Recently, a cell line was developed that was able to produce high titers of replication-deficient SV40 particles with no detectable replication-competent revertant SV40 virions [85]. While the small size of SV40 precludes the packaging of larger transgenes, its high transduction efficiency, ability to produce high titers, versatile specificity, ease of administration, capacity to infect quiescent cells, low immunogenicity and high tolerogenicity make SV40 a potentially important tool for LTGT as the most immediate safety issues are addressed. 
A

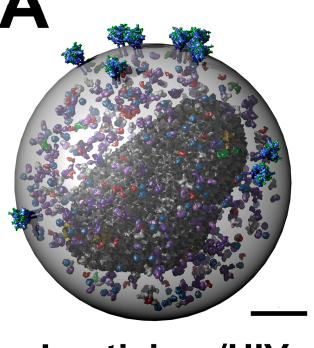

Lentivirus/HIV
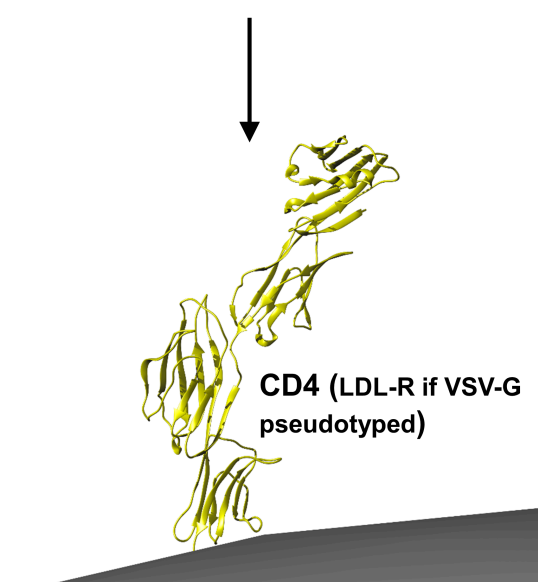

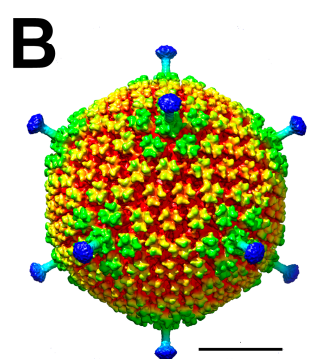

Adenovirus<smiles>CCCC[Tl]</smiles>

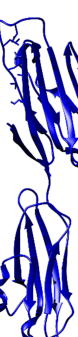

C

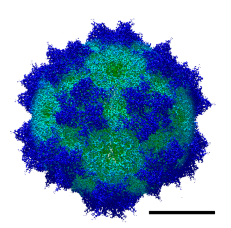

Adenoassociated virus
D

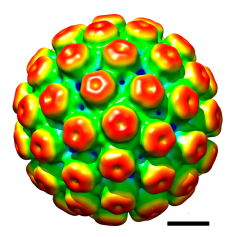

SV40

Plasma membrane

Figure 1. Viral vectors used in liver-targeted gene therapy. (A) Lentiviral vectors are able to transduce dividing and non-dividing cells and have their origin in HIV (rendered as cellPACK molecular model) [86]. HIV-based vectors bind to CD4 receptors (PDB ID: 1WIO) [87] as well as to CCR5 or CXCR4 coreceptors, mediating entry into the host cell via a cell-viral membrane fusion mechanism. Several lentiviral vectors are pseudotyped with vesicular stomatitis virus glycoprotein (VSV-G), as well as envelope glycoproteins of other vesiculoviruses, the cognate receptor of which is the low-density lipoprotein receptor (LDL-R) [16,17]. Scale bar = $300 \AA$ A. (B) Adenoviruses (EMDB ID: EMD-5538) [88] enter cells via attachment to the Coxsackie adenovirus receptor (CAR) (PDB ID: 3JZ7) [89], then attachment to $\alpha v \beta 3 / 5$ integrins. Receptor attachment triggers clathrin-mediated, dynamin-dependent endocytosis, with subsequent endosomal escape, cytosolic transport via microtubules and DNA nuclear import via engagement with the nuclear pore complex (NPC). Adenoviruses can also enter the cell via CAR-independent mechanisms by binding to factor XI and factor $\mathrm{X}$, then subsequent cellular binding to heparan sulfate proteoglycans (HSPGs) or the LDL-R-related protein [90]. Scale bar $=300 \AA$. (C) Adeno-associated viruses (EMDB ID: EMD-9012) [91] attach to cells first via HSPGs, then by engagement with the adeno-associated virus receptor (AAVR) (PDB ID: 6NZ0) [92], subsequently entering the cell via a clathrin-mediated or caveolin-mediated endocytosis mechanism, although AAVR-independent mechanisms have been postulated. More recently, a highly conserved G-protein coupled receptor, GPR108, was identified, which plays an important role in viral entry and nuclear localization [93]. Virions are then trafficked via endosomes to the trans-Golgi network, ultimately leading to escape into the cytoplasm and engagement with the NPC for nucleoplasm mobilization, followed by partial uncoating and genome release. Productive cell infection is dependent upon concomitant adenovirus or herpesvirus infection. Scale bar $=100 \AA$ A. (D) Simian virus 40 (SV40) (EMDB ID: EMD-5187) [94] binds to the cell membrane via attachment of its surface VP1 pentamer to GM1 ganglioside (PDB ID: 3BWR) [95], with subsequent caveolin-dependent endocytosis and targeting the endoplasmic reticulum (ER) via endosomal trafficking. In the ER, viral capsid destabilization via the reduction of disulfide bonds leads to ER membrane penetration and viral escape into the cytosol. It is unclear whether the viral capsid disassembles prior to or after engagement with the NPC. Scale bar $=100 \AA$. Virus-receptor interactions are not to scale. All images rendered using UCSF Chimera [96]. 


\section{Non-Viral Vectors}

\subsection{Sleeping Beauty Transposon}

Recognized as the first transposon-based system capable of gene transfer in vertebrate organisms, the Sleeping Beauty (SB) system, a transposon of the Tc1/mariner superfamily, uses a cut-and-paste mechanism for somatic gene transfer at TA dinucleotide sites and insertional mutagenesis [97,98]. $S B$ displays considerable specificity at TA dinucleotide sites with additional potential specificity conferred by palindromic AT consensus sites [99], as well as DNA strand deformation [100]. A comparative study of $S B$, piggyBac, Moloney murine leukemia virus (MMLV) and HIV vector insertional site selection properties in $C D 4^{+} \mathrm{T}$ cells found that $S B$ had the highest probability of insertion into a safe harbor locus [101]. Additionally, there have been no reported preclinical $S B$-associated adverse effects [102-105]. The power of $S B$ in identifying cancer driver genes is well known when used in systems with conditional transposase expression in various genetic backgrounds, including a recent murine study that used $S B$ to identify drivers of erythroleukemia in mice [106]. While intentional insertional mutagenesis is a powerful application of $S B$, the risk of unintentional insertional mutagenesis appears to be mitigated by the specific conditions under which insertional mutagenesis occurs. For example, the use of transgenic mice constitutively expressing both transposon and transposase, as well as a specific genetic background (p53+/-, etc.), are examples of conditions that impact the rate of unintentional insertional mutagenesis. It has been estimated that the risk of $S B$ transposon remobilization leading to an adverse effect is about $10^{-11}$ [107].

$S B$ has been successfully used in murine models of hemophilia A, hemophilia B, AAT, $\beta$-glucuronidase deficiency (mucopolysaccharidosis type VII), $\alpha$-L-iduronidase deficiency (mucopolysaccharidosis type I) and hereditary tyrosinemia (Fah deficiency), with encouraging results [108-110]. It has been used for the in vivo overexpression of low-density lipoprotein and very low-density lipoprotein receptors, resulting in moderate reductions in plasma cholesterol and atherosclerosis in a murine model of familial hypercholesterolemia [111]. A study using a murine von Willebrand disease model found that $S B$ transposon-mediated von Willebrand factor (VWF) gene delivery resulted in the long-term expression of supraphysiologic VWF levels [112]. While SB has been approved for certain clinical trials, delivery mechanisms to efficiently target livers in large animals are still under investigation. Further studies to fully characterize the inherent risk of transposase remobilization that could lead to genotoxic adverse reactions, including unintentional insertional mutagenesis, are warranted, notwithstanding the safety profile observed in preclinical studies.

\section{2. piggyBac Transposon}

The piggyBac DNA transposon was originally identified in baculovirus mutants as a host sequence in the cabbage looper Trichoplusia ni $[113,114]$. The piggyBac $(P B)$ transposon-transposase system is known for its ability to insert at TTAA sites via a cut-and-paste mechanism similar to that of $S B$ and to carry a larger transgene (as large as $100 \mathrm{~kb}$ ) [115] as well as for its ability to precisely excise without leaving a genetic footprint [116]. $P B$ has been used to transduce murine liver cells in vivo with the long-term stable expression of transgene $[117,118]$. $P B$ has also been used to deliver cDNA encoding factor VIII in a murine model of hemophilia $\mathrm{A}$, resulting in the stable expression of circulating factor VIII for over 300 days [119]. A codon-optimized PB transposase with enhanced activity was used in a murine model of hemophilia B with supraphysiologic factor IX expression for more than 12 months [120]. Regarding the risk of insertional mutagenesis, $P B$ was tested in a sensitive HCC-prone murine model, with no tumor induction observed [120]. While PB demonstrated integration preference higher to that of $S B$, the overall integration profile of $S B$ was more favorable to that of $P B$ in primary human $T$ lymphocytes [121]. The in vivo risk of insertional mutagenesis with $P B$ remains to be determined. 


\subsection{Naked Nucleic Acids and Synthetic Delivery Vectors}

Various methods for the delivery of DNA have been devised, including the injection of naked nucleic acids, hydrodynamic delivery, gene guns, sonoporation, electroporation and magnetofection, all used in small animals [122-126]. Since the half-life of intravenously delivered naked DNA is in the order of $\sim 10 \mathrm{~min}$ in mice [127], the sequestration of DNA in a synthetic nanoparticle to protect from circulating endonucleases would increase time in circulation and ensure delivery to the target tissue. Indeed, various synthetic non-viral vectors have been developed, including liposomes [128,129], inorganic nanoparticles [130], polymers (such as linear polymers, branched polymers, dendrimers and polysaccharides) [131-133], polymersomes [134] and cell-penetrating peptides [135]. While there have been multiple successful applications of synthetic vectors, notably the conjugation of trivalent $\mathrm{N}$-acetylgalactosamine to siRNA therapeutics (discussed below), various barriers to their widespread use remain. Such barriers include the potential for aggregation and disassembly in various physiologic conditions, potentially leading to microemboli in capillary beds, as well as clearance by macrophages [136] and effective nuclear delivery [137]. Further studies to identify the optimal synthetic vector(s) for LTGT are required, although their utility in FDA-approved therapeutics is encouraging.

\section{RNA-Based Therapeutics as Gene Suppression Tools}

\subsection{Small Interfering RNAs}

More recently, approaches to silence gene transcripts, thereby suppressing the translation of the respective gene products, have had promising clinical results in LTGT, with efficient non-viral delivery to hepatocytes. A small interfering RNA (siRNA), givosiran, bound to trivalent $N$-acetylgalactosamine specific to the asialoglycoprotein receptor on hepatocytes and delivered subcutaneously, targets and down regulates the translation of $\delta$-aminolevulinic acid synthase 1 messenger RNA (mRNA). It was recently approved by the FDA to reduce the frequency of attacks of acute intermittent porphyria [138]. Another siRNA treatment, patisiran, which is delivered via liposome, was recently FDA approved for the treatment of transthyretin-related hereditary amyloidosis, a rare autosomal dominant disease which results in misfolded transthyretin and leads to diffuse polyneuropathy and nonischemic cardiomyopathy [139]. Alnylam, the producing firm, has several other products in their pipeline at various stages of clinical trials for PH1 (lumasiran) [140], hemophilia (fitusiran) [141] and HBV infection (ALN-HBV02) [142], among others. Another firm, Moderna, has several products in their pipeline at various stages of clinical investigation based on mRNA delivered via lipid nanoparticles. Their preclinical work includes mRNA encoding arginase 1 in a murine model of arginine deficiency, with moderate and stable expression levels [143]. Given the mechanism of siRNA-based gene therapy, there are questions regarding the optimal dosing required to achieve an acceptable level of therapeutic effect. For example, patisiran dosing is by IV every three weeks, and givosiran dosing is given subcutaneously every month. The frequency of dosing is one important consideration, in that siRNA-based therapies will require dosing for the rest of the patient's life, whereas therapies administered via viral or non-viral vectors might not require repeated dosing.

\section{2. microRNAs}

MicroRNAs (miRNAs), which are short, non-coding, regulatory endogenous RNAs, about 19-25 nucleotides in length, have been implicated in hepatitis, cirrhosis and HCC [144-146]. The aforementioned deletion of miR-221/222 via adenoviral vector delivery resulted in attenuated hepatic fibrosis in a mouse model of NASH [28], while its reintroduction had the opposite effect. Another miRNA, miR-122, which is ubiquitously and specifically expressed in mammalian liver [147,148], appears to be involved in the pathogenesis of multiple liver diseases, from viral hepatitis via hepatitis C virus (HCV) [149], to hepatic steatosis [150], and HCC [151,152]. Antagomirs specific to miR-122 have been shown to improve NASH [150], as well as the inhibition of HCV viral replication and translation [149,153]. Lastly, miR-26a appears to be significantly down regulated in HCC [154]. Hepatic 
delivery of miR-26a via AAV in a murine model of HCC resulted in the suppression of tumorigenesis and the induction of tumor-specific apoptosis [154]. Though these studies showed efficacy of delivery using viral vectors, non-viral vectors have also been utilized to deliver miRNAs. Various non-viral vectors include liposomes, cell-derived membrane vesicles, gold nanoparticles and other inorganic material-based systems, as well as polymeric- and dendrimer-based vectors [155].

\section{Genome Editing}

The capacity for genetic engineering has enabled progressively more precise and specific applications through the recent creation of double-stranded breaks (DSBs) at specific target sequences. The monogenic nature of many inherited hepatic disorders makes endogenous DNA repair feasible with the evolution of more sophisticated gene editing techniques. Early developments of homologous recombination, single-stranded oligonucleotides and triplex DNA were important in foreshadowing the new era of gene editing for liver diseases [108-110].

\subsection{Zinc Finger Nucleases}

Zinc finger nucleases (ZFNs) are recombinantly engineered endonucleases comprising the DNA-binding domain of zinc finger proteins fused to the C-terminal DNA cleavage domain of the Flavobacterium okeanokoites FokI restriction enzyme (Figure 2A) [156]. Their adaptability and versatility have been demonstrated in numerous successful applications in LTGT, most notably the in vivo correction of factor IX deficiency in a murine model of hemophilia B [157]. The combination of ZFNs with viral vectors, specifically recombinant adeno-associated virus (rAAV), has led to the correction of hemophilia A and B in adult mice, as well as lysosomal enzyme deficiencies in Fabry and Gaucher diseases, along with Hurler and Hunter syndromes [158,159]. Though ZFNs are considered a feasible component of the LTGT armamentarium, there continues to be concern over the frequency of off-target cleavage events.

\subsection{Transcription Activator-Like Effector Nucleases}

Transcription activator-like effector nucleases (TALENs) are recombinantly engineered nucleases comprising the DNA recognition domain of the Xanthomonas transcription activator-like effector fused to the DNA cleavage domain of the FokI restriction enzyme (Figure 2B). In LTGT, murine hepatocytes were engineered using TALENs to be deficient in UGT1A1, thus deriving an in vitro model of Crigler-Najjar syndrome type 1 [160]. An additional study found that hepatitis C virus (HCV) entry into Huh-7.5 cells was significantly impaired in a claudin-1-dependent manner when diacylglycerol acyltransferase-1 expression was silenced using TALENs [161]. The large size of TALENs and epigenetic modifications impairing access to the desired chromosomal site are significant challenges for use in a clinical setting.

\subsection{Clustered Regularly Interspaced Short Palindromic Repeats}

Bacteria and archaea possess adaptive immune defense mechanisms such as clustered regularly interspaced short palindromic repeats (CRISPR), which are highly conserved, repeating and non-contiguous loci. The CRISPR loci are transcribed as precursor CRISPR RNAs (pre-crRNAs), which bind to trans-activating crRNA to form duplex RNAs that are cleaved by one of the CRISPR-associated (Cas) genes, namely Cas9, that encodes a double-stranded RNA-specific ribonuclease RNase III (Figure 2C) [162]. The cleavage product of Cas9-duplex RNA interaction is a single-stranded guide RNA (gRNA), which binds to Cas9. As with ZFNs and TALENs, CRISPR/Cas9 cleaves DNA to form DSBs, which are then repaired by homologous recombination (HR) or nonhomologous end joining (NHEJ) [163,164]. 


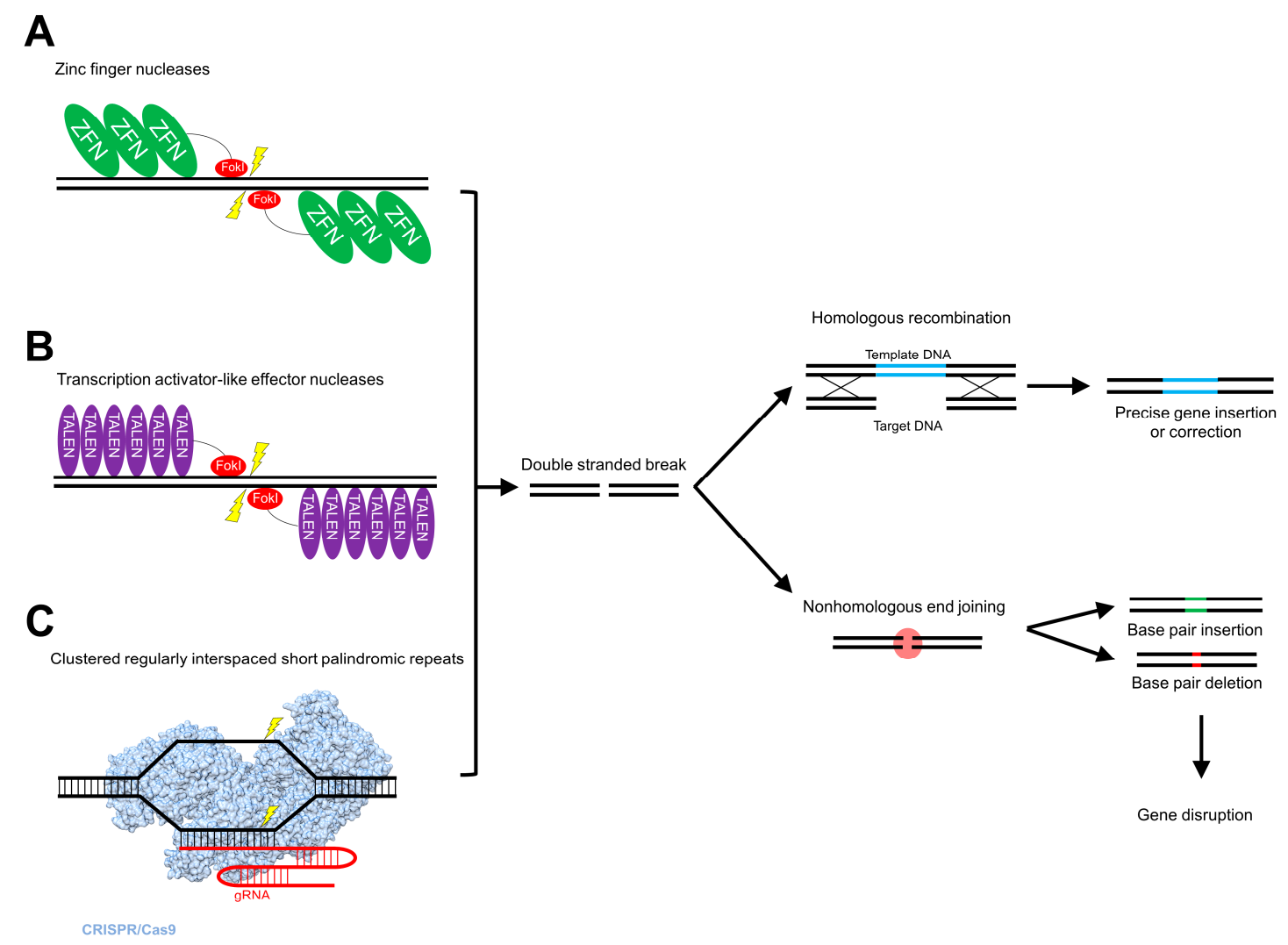

Figure 2. Recombinantly engineered nucleases utilize endogenous DNA repair mechanisms for genome editing. (A) Zinc finger nucleases (ZFNs), covalently bound to the FokI restriction enzyme nuclease domain, dimerize and generate double-stranded breaks (DSBs) in target DNA. (B) Similarly, transcription activator-like effector nucleases (TALENs) bind to target DNA, and the FokI nuclease domain generates DSBs. (C) Clustered regularly interspaced short palindromic repeats (CRISPR) bound to CRISPR-associated protein 9 (Cas9) contain a guide RNA (gRNA) (PDB ID: 5U0A) [165]. Through hybridization of the gRNA to the target region, DSBs are generated at specific sites, with subsequent insertion of the donor DNA. DSBs are a substrate for two endogenous DNA repair mechanisms; homologous recombination (HR) and nonhomologous end joining (NHEJ). HR results in the integration of donor DNA with precision and fidelity, whereas NHEJ results in insertions and deletions at the DSB cleavage site of varying base pair lengths, thus resulting in gene disruption, without the insertion of donor DNA. The inability to favor one mechanism over another results in off-target effects and unintended mutations, insertions and deletions inherent to these endogenous mechanisms.

CRISPR/Cas9 has been used in hereditary tyrosinemia to correct the Fah mutation in a mouse model [166]. Murine AAV vector delivery of CRISPR/Cas9 targeted to the low-density lipoprotein receptor induced severe hypercholesterolemia and atherosclerosis [167]. An in vitro study using induced pluripotent stem cell-derived hepatocyte-like cells (iHLCs) with an engineered deactivated Arg1 locus (which encodes arginase-1) demonstrated the utility of CRISPR/Cas9 to reincorporate excised Arg1 exons and thus reconstitute arginase function in arginase-1 deficiency [168]. Recently, human AAT was somatically incorporated into mouse liver using CRISPR/Cas9 with an adenoviral vector to achieve stable expression for $>200$ days [169]. Lastly, skin fibroblasts from a patient with PH1 were reprogrammed ex vivo into iHLCs [170]. The PH1-iHLCs containing the defective liver-specific enzyme AGT underwent CRISPR/Cas9 gene delivery of an AGXT therapeutic minigene, inserting into a safe harbor locus without detectable off-target insertions [171].

Several more recent LTGT applications demonstrate the ability of the CRISPR/Cas9 system to eradicate chronic HBV infection in duck hepatocytes, via the targeted inhibition of covalently closed circular DNA (cccDNA) [172]. Another in vitro study using human HepG2 cells demonstrated the 
efficient degradation of HBV cccDNA using Streptococcus pyogenes (Sp) and Streptococcus thermophilus (St) Cas9 [173]. HBV genome inhibition in mice was recently reported using Staphylococcus aureus Cas9 delivered using an AAV vector [174]. Lastly, a clinical trial of 10 patients with HCC currently underway in China uses CRISPR to engineer autologous $P D-1$ knockout $\mathrm{T}$ lymphocytes ex vivo. Following transcatheter arterial chemoembolization to obliterate the vascular supply, percutaneously administered autologous $P D-1$ knockout cells are delivered to the tumor periphery to ascertain the response rate and progression-free survival (NCT04417764). This approach, if successful, has exciting implications in the treatment of HCC.

Based on the observation of off-target insertions with CRISPR-based genome editing, there has been significant discussion regarding the risk of insertional mutagenesis and the development of cancer. The generation of DSBs by conventional CRISPR-based methods leads to the activation of p53 [175], which can interfere with CRISPR genome editing. There is concern that the selection of cells modified by CRISPR could include cells with $p 53$ mutations, posing a significant risk of cancer. Of note, a murine study demonstrated the direct mutation of $p 53$ and Pten genes, resulting in the induction of hepatocellular carcinoma (HCC) [176]. The potential risk of cancer has led to the development of novel techniques based on CRISPR that avoid the generation of DSBs.

An approach called base editing utilizes a catalytically impaired Cas 9 fused to a base modification enzyme (a cytosine base editor that generates uracil, or an adenine base editor that generates inosine) as well as to a uracil DNA glycosylase inhibitor (Figure 3A) $[177,178]$. The fusion protein is bound to a guide RNA that displaces a small segment in the target region and uses single-stranded DNA as a substrate to generate a nick in the non-edited strand. To prevent the endogenous base excision repair mechanism from reversing the engineered base modification, the uracil DNA glycosylase inhibitor blocks the action of uracil $\mathrm{N}$-glycosylase to remove the base from the DNA backbone. A recent exciting application of this approach was the correction of murine phenylketonuria via the AAV delivery of CRISPR/Cas9 base editing agents [179]. A newer approach, termed prime editing, utilizes a catalytically impaired Cas9 fused to reverse transcriptase to allow for direct copying of genetic information into the target site without the induction of DSBs and the potential for genomic mutations (Figure 3B) [180]. Such technical advances, which appear to mitigate the risk of off-target insertions and deletions associated with DSBs, are exciting breakthroughs that will enhance the utility of genome editing approaches. 

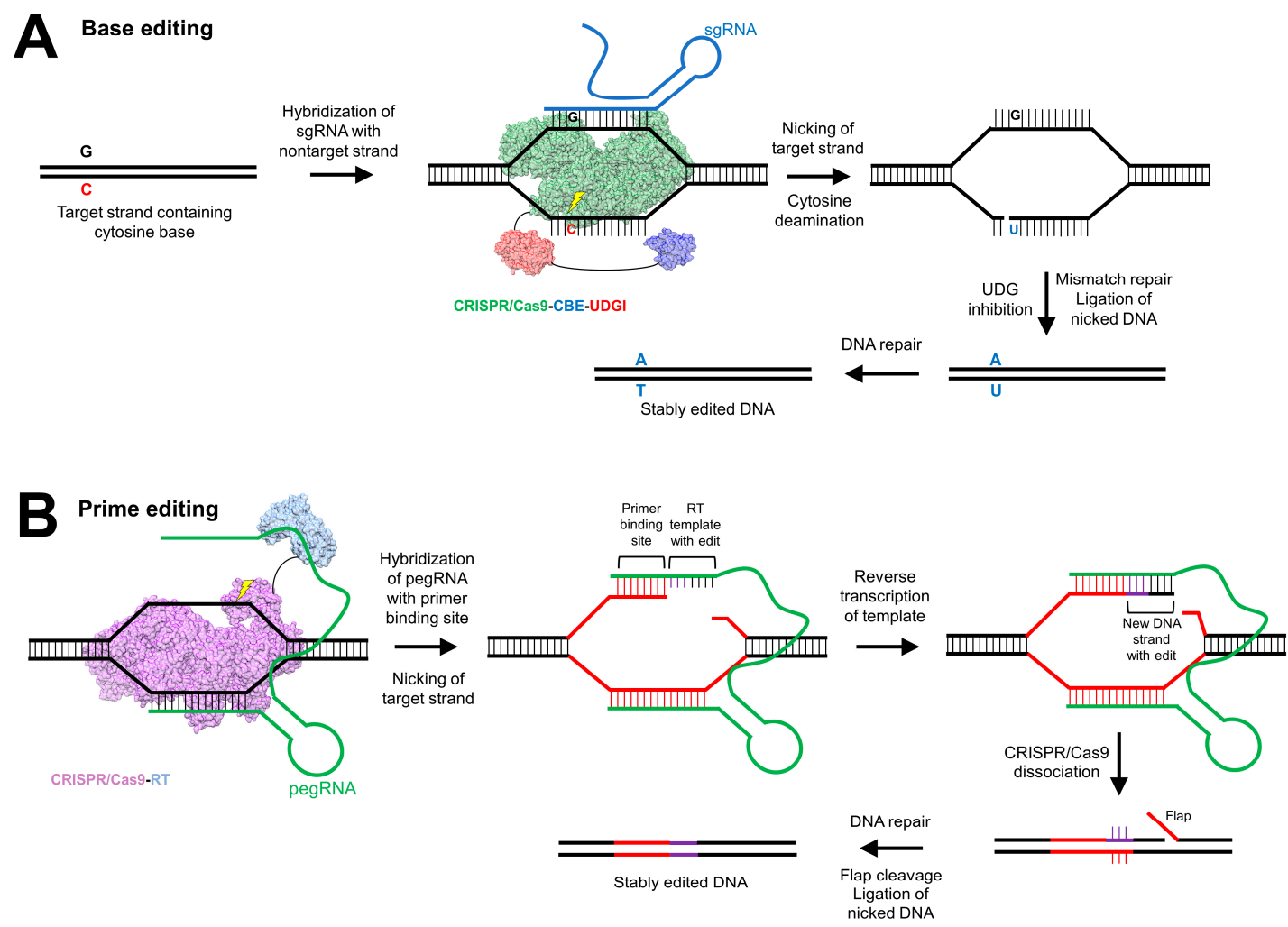

Figure 3. Base editing and prime editing use catalytically impaired Cas9 nuclease for single-strand nicking. (A) Base editing utilizes a catalytically impaired Cas9 nuclease (PDB ID: 5U0A) [165] fused with a cytosine base editor (CBE) (PDB ID: 1MQ0) [181] (or, alternatively, an adenine base editor), as well as a uracil DNA glycosylase inhibitor (UDGI) (PDB ID: 1UGH) [182]. The CRISPR/Cas9-CBE-UDGI also contains a single-guide RNA (sgRNA), which hybridizes with a target strand containing a cytosine-guanine base pair. The sgRNA binds to the nontarget strand containing the guanine base, and the Cas9 nuclease performs a single-stranded break ("nicking") of the target strand on the 5" end of the target cytosine base. The CBE domain catalyzes cytosine deamination to generate uracil on the target DNA strand, which is a substrate for the endogenous base excision repair (BER) mechanism. The UDGI domain suppresses BER, favoring mismatch repair to replace guanine on the nontarget strand with adenine. The nicked target strand is ligated, and through DNA repair, uracil on the target strand is replaced with thymidine, thus generating an adenine-thymidine base pair and stably edited DNA. (B) Prime editing uses a catalytically deficient Cas9 capable only of nicking (PDB ID: 5U0A) [165], fused to the Moloney murine leukemia virus reverse transcriptase (PDB ID: 1MML) [183], and bound to a prime editing guide RNA (pegRNA) that targets the region of interest in genomic DNA. After cleavage of the target strand, the pegRNA hybridizes with the primer binding site. Adjacent to this site on the pegRNA is the reverse transcriptase (RT) template with the gene editing template. The RT motif reverse transcribes the target strand using the pegRNA as a template. Once the pegRNA dissociates, the 3' end with the reverse transcribed insertion binds to the nontarget DNA with a mismatch at the gene editing site. There is a flap at the $5^{\prime}$ end of the nicked strand that is cleaved off, and the nicked ends are subsequently ligated. The mismatched base pairs undergo DNA repair to generate stably edited DNA.

\section{Future Perspectives}

The exciting prospects for liver-targeted gene therapy in the age of precise targeting and genome editing, with an ever-expanding array of therapeutics in clinical trials and on the market (summarized in Table 1), hold special promise for the treatment of monogenic metabolic disorders. As outlined above, one overarching principle is mitigating the risk of insertional mutagenesis, as the preclinical success of novel approaches may be masked by inherent oncogenic risk. Robust studies should be carried out that comprehensively characterize the oncogenic risk of all gene therapy approaches that involve genomic 
integration. Closely related to this is the specificity of various approaches; for example, the specificity of CRISPR is a topic of ongoing debate, and while approaches such as base editing and prime editing provide an opportunity to optimize specificity, preclinical studies using these two approaches are scant. Furthermore, and this is especially true for viral vectors, innate and adaptive immune responses against both the vector and the payload need to be taken into account, as work in preclinical animal models often does not translate to clinical trials. The employment of strict exclusion criteria to account for seropositive patients likely to have a suboptimal response will continue and will likely broaden to multifactorial exclusion criteria based on genotypic factors. Payload size is another rate-limiting step in the further development of various viral and non-viral vectors, as many vectors are only capable of delivering transgenes less than $10 \mathrm{~kb}$. Lastly, given the high cost of research and development for many of these therapeutics and their exorbitant prices when they reach the market, regulatory frameworks from both the FDA and the Europe Medicines Agency (EMA) aim to shorten the time of development and speed up the time to clinical trials. This will undoubtedly reduce development costs and the potential financial burden to the healthcare system. In summary, the optimization of viral and non-viral vectors to improve specificity and mitigate oncogenicity, the more complete characterization of vector safety profiles, the broader screening of patients for clinical trials and the development of regulatory frameworks to expedite these products to market with greater safety and reduced cost are critical factors in the application of liver-targeted gene therapy to a myriad of disorders. 
Table 1. Summary of preclinical and clinical trials of liver targeted gene therapy.

\begin{tabular}{|c|c|c|c|c|c|}
\hline Vector & Payload & Disorder & $\begin{array}{c}\text { Preclinical Results/Clinical Trial } \\
\text { Endpoints }\end{array}$ & Clinical Trial/Phase & References \\
\hline Retroviral & Factor VIII & Hemophilia A & Physiologic FVIII levels (mice) & & [6] \\
\hline Lentiviral & Factor IX & Hemophilia B & $\begin{array}{l}\text { Supraphysiologic FIX levels (nonhuman } \\
\text { primates) }\end{array}$ & & {$[20]$} \\
\hline Lentiviral & Factor IX & Hemophilia B & $\begin{array}{l}\text { Sustained FIX expression, prevention of } \\
\text { NAb induction (mice) }\end{array}$ & & [21] \\
\hline Lentiviral & CRISPR/Cas9 & Hepatitis B & $\begin{array}{l}\text { Inhibition of HBV replication in vivo } \\
\text { (mice) and in vitro }\end{array}$ & & {$[22,23]$} \\
\hline Lentiviral & Factor IX & Hemophilia B & $\begin{array}{l}\text { Ex vivo stem cell gene correction and } \\
\text { autologous stem cell transplant }\end{array}$ & NCT03961243/Phase I & \\
\hline Adenoviral & UGT1A1 & Crigler-Najjar type I & Correction of hyperbilirubinemia (rats) & & [26] \\
\hline Adenoviral & Human aquaporin 1 & $\begin{array}{l}\text { Estrogen-induced } \\
\text { cholestasis }\end{array}$ & $\begin{array}{l}\text { Lower serum bile salt concentration, } \\
\text { improved biliary output (rats) }\end{array}$ & & {$[27]$} \\
\hline Adenoviral & miR-221/222 & NASH & Decreased hepatic fibrosis (mice) & & [28] \\
\hline HDAd/Sleeping Beauty & Factor IX & Hemophilia B & Stable FIX expression (dogs) & & {$[39,40]$} \\
\hline HDAd & AGT & Primary hyperoxaluria 1 & $\begin{array}{c}\text { Stable transgene expression, decreased } \\
\text { hyperoxaluria (mice) }\end{array}$ & & [41] \\
\hline HDAd & $A A T$ & AAT deficiency & $\begin{array}{c}\text { Stable AAT expression (nonhuman } \\
\text { primates) }\end{array}$ & & [32] \\
\hline AAV & Factor IX & Hemophilia B & $\begin{array}{l}\text { FIX expression decreased by } 92 \% \\
\text { following } 2 / 3 \text { hepatectomy (mice) }\end{array}$ & & {$[48]$} \\
\hline AAV & Factor IX & Hemophilia B & Robust FIX expression levels (mice) & & [49] \\
\hline AAV & $\begin{array}{c}\text { Copper transporting ATPase } \\
2\end{array}$ & Wilson's disease & $\begin{array}{c}\text { Normalized serum holoceruloplasmin } \\
\text { levels and hepatic parenchymal copper } \\
\text { levels (mice) }\end{array}$ & & [58] \\
\hline AAV & Human porphobilinogen & $\begin{array}{l}\text { Acute intermittent } \\
\text { porphyria }\end{array}$ & $\begin{array}{l}\text { Reduced frequency of biochemical } \\
\text { attacks, degree of neuropathy (mice) }\end{array}$ & & {$[59,60]$} \\
\hline AAV & Propionyl-CoA & Propionyl acidemia & Decreased serum toxin level (mice) & & [61] \\
\hline AAV & $\begin{array}{c}\text { Human } \\
\text { methylmalonyl-CoA mutase }\end{array}$ & Methylmalonic acidemia & $\begin{array}{l}\text { Correction of acidemia, prevention of } \\
\text { murine neonatal lethality }\end{array}$ & & [62] \\
\hline AAV & Phenylalanine hydroxylase & Phenylketonuria & $\begin{array}{l}\text { Reduced serum phenylalanine levels } \\
\text { (mice) }\end{array}$ & & [63] \\
\hline AAV & Glucose-6-phosphatase & $\begin{array}{l}\text { Glycogen storage disease } \\
\text { type Ia }\end{array}$ & $\begin{array}{c}\text { Stable G6P expression, correction of } \\
\text { hypoglycemia, normalized hepatic } \\
\text { glycogen and reduced hepatic steatosis } \\
\text { (mice, dogs) }\end{array}$ & & {$[64,65]$} \\
\hline
\end{tabular}


Table 1. Cont

\begin{tabular}{|c|c|c|c|c|c|}
\hline Vector & Payload & Disorder & $\begin{array}{l}\text { Preclinical Results/Clinical Trial } \\
\text { Endpoints }\end{array}$ & Clinical Trial/Phase & References \\
\hline AAV & $A B C B 4$ & $\begin{array}{c}\text { Progressive familial } \\
\text { intrahepatic cholestasis } 3\end{array}$ & $\begin{array}{l}\text { Stable } \mathrm{ABCB} 4 \text { expression, reduced } \\
\text { progression of liver fibrosis (mice) }\end{array}$ & & {$[66]$} \\
\hline AAV & Factor VIII & Hemophilia A & Stable FVIII expression (dogs) & & {$[67,68]$} \\
\hline AAV & Factor IX & Hemophilia B & Stable FIX expression & NCT00979238/Phase I & [69] \\
\hline AAV & Factor VIII & Hemophilia A & Stable FVIII expression & NCT02576795/Phase I/II & [45] \\
\hline AAV & Factor IX & Hemophilia B & Stable FIX expression & NCT02484092/Phase II & {$[70,71]$} \\
\hline AAV & Porphobilinogen deaminase & $\begin{array}{l}\text { Acute intermittent } \\
\text { porphyria }\end{array}$ & $\begin{array}{l}\text { Safety, not metabolic correction at doses } \\
\text { tested, varied results }\end{array}$ & NCT02082860/Phase I & {$[72]$} \\
\hline AAV & $L D L R$ & $\begin{array}{l}\text { Homozygous familial } \\
\text { hypercholesterolemia }\end{array}$ & Improvement of lipid profile & NCT02651675/Phase I/II & \\
\hline AAV & $\begin{array}{l}\text { Padua variant factor IX } \\
\text { Fidanacogene }\end{array}$ & Hemophilia B & Supraphysiologic FIX expression level & NCT03569891/Phase III & \\
\hline AAV & $\begin{array}{l}\text { elaparvovec (high activity } \\
\text { factor IX) }\end{array}$ & Hemophilia B & Supraphysiologic FIX expression level & NCT03587116/Phase III & \\
\hline AAV & $\begin{array}{l}\text { GS010 (human wild-type } \\
\text { ND4) }\end{array}$ & $\begin{array}{l}\text { Leber hereditary optic } \\
\text { neuropathy }\end{array}$ & Recovery of vision & $\begin{array}{c}\text { NCT02652780 } \\
\text { NCT02652767 } \\
\text { NCT03293524, all Phase } \\
\text { III }\end{array}$ & \\
\hline AAV & $\begin{array}{c}\text { LYS-SAF302 } \\
\text { (N-sulfoglucosamine } \\
\text { sulfohydrolase) }\end{array}$ & $\begin{array}{l}\text { Mucopolysaccharidosis } \\
\text { IIIA }\end{array}$ & $\begin{array}{l}\text { Improvement or stabilization of } \\
\text { neurodevelopmental state }\end{array}$ & NCT03612869/Phase III & \\
\hline AAV & NSR-REP1 (REP1) & Choroideremia & $\begin{array}{l}\text { Improvement in best corrected visual } \\
\text { acuity }\end{array}$ & NCT03496012/Phase III & \\
\hline AAV & $\begin{array}{c}\text { Valoctocogene } \\
\text { roxaparvovec (factor VIII) }\end{array}$ & Hemophilia A & Improvement in FVIII median activity & $\begin{array}{c}\text { NCT03370913 } \\
\text { NCT03392974, both Phase } \\
\text { III }\end{array}$ & \\
\hline AAV & $\begin{array}{c}\text { Voretigene } \\
\text { neparvovec-rzyl (RPE65) }\end{array}$ & $\begin{array}{l}\text { Biallelic RPE65 } \\
\text { mutation-associated } \\
\text { retinal dystrophy }\end{array}$ & $\begin{array}{l}\text { Improvement in multi-lumen mobility } \\
\text { test scores }\end{array}$ & FDA approved & [73] \\
\hline AAV & $\begin{array}{c}\text { Onasemnogene } \\
\text { abeparvovec-xioi }(S M N)\end{array}$ & Spinal muscular atrophy & $\begin{array}{c}\text { Prevention of death and permanent } \\
\text { breathing support }\end{array}$ & FDA approved & {$[74]$} \\
\hline SV40 & UGT1A1 & Crigler-Najjar type I & $\begin{array}{l}\text { Normalization of murine ALT and } \\
\text { bilirubin serum levels, liver histology }\end{array}$ & & {$[82]$} \\
\hline Sleeping Beauty & Factor VIII & Hemophilia A & Stable FVIII expression & & [108-110] \\
\hline Sleeping Beauty & Factor IX & Hemophilia B & Stable FIX expression & & [108-110] \\
\hline
\end{tabular}


Table 1. Cont

\begin{tabular}{|c|c|c|c|c|c|}
\hline Vector & Payload & Disorder & $\begin{array}{l}\text { Preclinical Results/Clinical Trial } \\
\text { Endpoints }\end{array}$ & Clinical Trial/Phase & References \\
\hline Sleeping Beauty & $A A T$ & AAT deficiency & Stable AAT expression (mice) & & [108-110] \\
\hline Sleeping Beauty & $\beta$-glucuronidase & $\begin{array}{l}\text { Mucopolysaccharidosis } \\
\text { type VII }\end{array}$ & Stable $\beta$-glucuronidase expression (mice) & & [108-110] \\
\hline Sleeping Beauty & $\alpha$-L-iduronidase & $\begin{array}{l}\text { Mucopolysaccharidosis } \\
\text { type I }\end{array}$ & Stable $\alpha$-L-iduronidase expression (mice) & & [108-110] \\
\hline Sleeping Beauty & Fah & Hereditary tyrosinemia & Stable Fah expression (mice) & & [108-110] \\
\hline Sleeping Beauty & $L D L R, V L D L R$ & $\begin{array}{c}\text { Familial } \\
\text { hypercholesterolemia }\end{array}$ & $\begin{array}{c}\text { Moderate reduction in plasma } \\
\text { cholesterol and atherosclerosis (mice) }\end{array}$ & & [111] \\
\hline Sleeping Beauty & von Willebrand factor & von Willebrand disease & Supraphysiologic VFW levels (mice) & & [112] \\
\hline piggyBac & Factor VIII & Hemophilia A & Stable FVIII expression & & {$[119]$} \\
\hline piggyBac & Factor IX & Hemophilia B & Stable FIX expression & & [120] \\
\hline $\begin{array}{c}\text { Non-viral (trivalent } \\
\text { N-acetylgalactosamine) }\end{array}$ & Givosiran (siRNA) & $\begin{array}{l}\text { Acute intermittent } \\
\text { porphyria }\end{array}$ & $\begin{array}{l}\text { Silences } \delta \text {-aminolevulinic acid synthase } 1 \\
\text { mRNA, reduces AIP attack frequency }\end{array}$ & FDA approved & [138] \\
\hline Non-viral (liposomes) & Patisiran (siRNA) & $\begin{array}{l}\text { Transthyretin-related } \\
\text { hereditary amyloidosis }\end{array}$ & Improvement in polyneuropathy & FDA approved & [139] \\
\hline $\begin{array}{c}\text { Non-viral (trivalent } \\
\text { N-acetylgalactosamine) }\end{array}$ & Lumasiran (siRNA) & Primary hyperoxaluria 1 & $\begin{array}{c}\text { Decreased hyperoxaluria by silencing } \\
\text { glycolate oxidase }\end{array}$ & NCT02706886/Phase I/II & [140] \\
\hline $\begin{array}{c}\text { Non-viral (trivalent } \\
\text { N-acetylgalactosamine) }\end{array}$ & Fitusiran (siRNA) & Hemophilia A \& B & $\begin{array}{c}\text { Reduces bleeding instances by silencing } \\
\text { antithrombin }\end{array}$ & NCT03417245/Phase III & [141] \\
\hline $\begin{array}{c}\text { Non-viral (trivalent } \\
\text { N-acetylgalactosamine) }\end{array}$ & ALN-HBV02 (siRNA) & Hepatitis B & Reduction in HBV surface antigen levels & NCT02826018/Phase I & {$[142]$} \\
\hline $\begin{array}{l}\text { Non-viral (lipid } \\
\text { nanoparticle) }\end{array}$ & Arginase 1 & Arginine deficiency & $\begin{array}{l}\text { Stable, moderate arginase } 1 \text { expression } \\
\text { (mice) }\end{array}$ & & [143] \\
\hline Non-viral (SQ injection) & miR-122 antagomir & $\mathrm{NASH}$ & $\begin{array}{l}\text { Improvement in hepatic steatosis and } \\
\text { reduction in plasma cholesterol (mice) }\end{array}$ & & [150] \\
\hline Non-viral (SQ injection) & miR-122 antagomir & Hepatitis C & $\begin{array}{l}\text { Inhibition of viral replication and } \\
\text { translation in vitro }\end{array}$ & & {$[149,153]$} \\
\hline AAV & miR-26A & Hepatocellular carcinoma & $\begin{array}{l}\text { Suppression of tumorigenesis and } \\
\text { induction of tumor-specific apoptosis } \\
\text { (mice) }\end{array}$ & & [154] \\
\hline AAV & Factor VIII, ZFN & Hemophilia A & Stable expression of FVIII (mice) & & [157] \\
\hline AAV & Factor IX, ZFN & Hemophilia B & Stable expression of FIX (mice) & & {$[158,159]$} \\
\hline AAV & $\begin{array}{c}\text { Human } \alpha \text {-galactosidase } A, \\
\text { ZFN }\end{array}$ & Fabry disease & $\begin{array}{l}\text { Stable expression of } \alpha \text {-galactosidase A } \\
\text { (mice) }\end{array}$ & & [159] \\
\hline
\end{tabular}


Table 1. Cont.

\begin{tabular}{|c|c|c|c|c|c|}
\hline Vector & Payload & Disorder & $\begin{array}{c}\text { Preclinical Results/Clinical Trial } \\
\text { Endpoints }\end{array}$ & Clinical Trial/Phase & References \\
\hline AAV & Acid $\beta$-glucosidase, ZFN & Gaucher disease & $\begin{array}{c}\text { Stable expression of acid } \beta \text {-glucosidase } \\
\text { (mice) }\end{array}$ & & [159] \\
\hline AAV & Iduronate-2 sulfatase, ZFN & Hunter syndrome & $\begin{array}{l}\text { Stable expression of iduronate-2 sulfatase } \\
\text { (mice) }\end{array}$ & & [159] \\
\hline AAV & $\alpha$-L-iduronidase, ZFN & Hurler syndrome & $\begin{array}{l}\text { Stable expression of } \alpha \text {-L-iduronidase } \\
\text { (mice) }\end{array}$ & & [159] \\
\hline Lentiviral & $\begin{array}{l}\text { TALENs targeting } \\
\text { diacylglycerol } \\
\text { acyltransferase-1 }\end{array}$ & Hepatitis C & $\begin{array}{l}\text { Viral entry impaired in a claudin-1 } \\
\text { dependent manner in vitro }\end{array}$ & & [161] \\
\hline $\begin{array}{l}\text { Non-viral (ssDNA } \\
\text { oligonucleotides) }\end{array}$ & Fah, CRISPR/Cas9 & Hereditary tyrosinemia & Correction of Fah mutation (mice) & & [166] \\
\hline AAV & CRISPR/Cas9 & $\begin{array}{c}\text { Induction of severe } \\
\text { hypercholesterolemia and } \\
\text { atherosclerosis }\end{array}$ & Via mutation of $L D L R$ (mice) & & [167] \\
\hline Adenoviral & AAT, CRISPR/Cas9 & AAT deficiency & $\begin{array}{l}\text { Somatic murine hepatic incorporation } \\
\text { and stable expression of AAT }\end{array}$ & & [168] \\
\hline AAV & CRISPR/Cas9 & Hepatitis B & Inhibition of genome replication in mice & & [173] \\
\hline $\begin{array}{l}\text { Non-viral (DNA } \\
\text { plasmids) }\end{array}$ & CRISPR/Cas9 & $\begin{array}{c}\text { Induction of } \\
\text { hepatocellular carcinoma }\end{array}$ & Via mutation of $p 53$ and Pten (mice) & & [176] \\
\hline None & $\begin{array}{l}\text { Ex vivo PD-1 knockout in } \\
\text { T lymphocytes engineered } \\
\text { via CRISPR }\end{array}$ & Hepatocellular carcinoma & $\begin{array}{c}\text { Tumor response rate, progression-free } \\
\text { survival }\end{array}$ & NCT04417764 & \\
\hline AAV & CRISPR/Cas9 & Phenylketonuria & $\begin{array}{c}\text { Correction of } P K U \text { mutation via base } \\
\text { editing (mice) }\end{array}$ & & [179] \\
\hline
\end{tabular}




\section{Conclusions}

Our expanding arsenal of techniques for gene editing and delivery systems herald a promising outlook for LTGT. Given the multitude of monogenic metabolic disorders that have been clinically and mechanistically described, the feasibility that LTGT could provide a cure to such disorders is potentially in reach. While many obstacles remain, particularly the additional characterization of safety and efficacy between the various systems, optimal delivery routes, circumventing vector immunogenicity and enhancing cell type specificity, the potential of LTGT to correct genetic deficiencies and improve quality of life in patients with disabling metabolic disorders is very promising. Now that many of these therapies translate to clinical trials, ensuring the safety, tolerogenicity and robust monitoring of adverse reactions will be of paramount importance. The combination of cutting-edge genome editing approaches with viral and non-viral vectors is a powerful approach that can transform the practice of medicine and cure many monogenic ailments. Future refinements of these methods could target polygenic disorders, and their ability to regulate gene expression could yield more effective therapeutics for a wide range of diseases. As these systems mature with improved safety and efficiency, the diversity of clinical trials will undoubtedly blossom and grow.

Funding: No grant funding was utilized in the preparation of this manuscript.

Conflicts of Interest: The authors report no conflict of interest.

\section{Abbreviations}

$\begin{array}{ll}\text { AAT } & \alpha-1 \text { antitrypsin } \\ \text { AAV } & \text { adeno-associated virus } \\ \text { AAVR } & \text { adeno-associated virus receptor } \\ \text { AGXT } & \text { alanine-glyoxylate aminotransferase } \\ \text { Arg1 } & \text { arginase-1 } \\ \text { Cas } & \text { CRISPR-associated gene } \\ \text { cCCDNA } & \text { covalently closed circular DNA } \\ \text { CRISPR } & \text { clustered regularly interspaced short palindromic repeats } \\ \text { DNA } & \text { deoxyribonucleic acid } \\ \text { DSB } & \text { double-stranded break } \\ \text { HBV } & \text { hepatitis B virus } \\ \text { HCC } & \text { hepatocellular carcinoma } \\ \text { HCV } & \text { hepatitis C virus } \\ \text { HDAd } & \text { helper-dependent adenovirus } \\ \text { HIV } & \text { human immunodeficiency virus } \\ \text { HR } & \text { homologous recombination } \\ \text { iHLC } & \text { induced hepatocyte-like cell } \\ \text { LTGT } & \text { liver-targeted gene therapy } \\ \text { MLV } & \text { murine leukemia virus } \\ \text { M-MLV } & \text { Moloney murine leukemia virus } \\ \text { NASH } & \text { non-alcoholic steatohepatitis } \\ \text { NHEJ } & \text { nonhomologous end joining } \\ \text { pegRNA } & \text { prime editing guide RNA } \\ \text { PH1 } & \text { primary hyperoxaluria type 1 } \\ \text { rAAV } & \text { recombinant adeno-associated virus } \\ \text { rAd } & \text { recombinant adenovirus } \\ \text { RNA } & \text { ribonucleic acid } \\ \text { rSV40 } & \text { recombinant simian virus 40 } \\ & \end{array}$




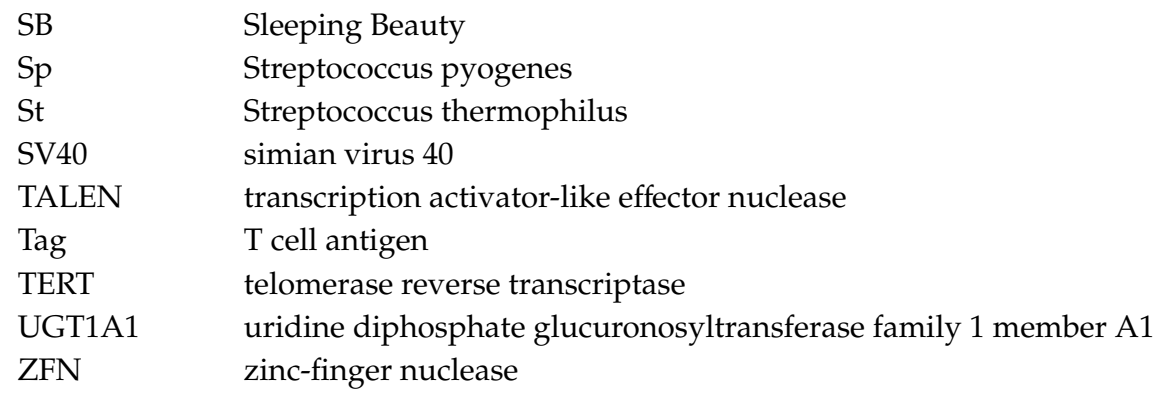

\section{References}

1. Qi, P.; Han, J.; Lu, Y.; Wang, C.; Zhu, B. A transient three-plasmid expression system for the production of hepatocytes targeting retroviral vectors. Acta Biochim. Biophys. Sin. 2007, 39, 567-574. [CrossRef] [PubMed]

2. Nguyen, T.H.; Loux, N.; Dagher, I.; Vons, C.; Carey, K.; Briand, P.; Hadchouel, M.; Franco, D.; Jouanneau, J.; Schwall, R.; et al. Improved gene transfer selectivity to hepatocarcinoma cells by retrovirus vector displaying single-chain variable fragment antibody against c-Met. Cancer Gene Ther. 2003, 10, 840-849. [CrossRef] [PubMed]

3. Nguyen, T.H.; Pagès, J.C.; Farge, D.; Briand, P.; Weber, A. Amphotropic retroviral vectors displaying hepatocyte growth factor-envelope fusion proteins improve transduction efficiency of primary hepatocytes. Hum. Gene Ther. 1998, 9, 2469-2479. [CrossRef]

4. Liu, M.L.; Winther, B.L.; Kay, M.A. Pseudotransduction of hepatocytes by using concentrated pseudotyped vesicular stomatitis virus G glycoprotein (VSV-G)-Moloney murine leukemia virus-derived retrovirus vectors: Comparison of VSV-G and amphotropic vectors for hepatic gene transfer. J. Virol. 1996, 70, 2497-2502. [CrossRef] [PubMed]

5. Miller, D.G.; Adam, M.A.; Miller, A.D. Gene transfer by retrovirus vectors occurs only in cells that are actively replicating at the time of infection. Mol. Cell. Biol. 1990, 10, 4239-4242. [CrossRef] [PubMed]

6. Xu, L.; Mei, M.; Ma, X.; Ponder, K.P. High expression reduces an antibody response after neonatal gene therapy with B domain-deleted human factor VIII in mice. J. Thromb. Haemost. 2007, 5, 1805-1812. [CrossRef]

7. Hacein-Bey-Abina, S.; Von Kalle, C.; Schmidt, M.; McCormack, M.P.; Wulffraat, N.; Leboulch, P.; Lim, A.; Osborne, C.S.; Pawliuk, R.; Morillon, E.; et al. LMO2-associated clonal T cell proliferation in two patients after gene therapy for SCID-X1. Science 2003, 302, 415-419. [CrossRef]

8. Young, G.R.; Stoye, J.P.; Kassiotis, G. Are human endogenous retroviruses pathogenic? An approach to testing the hypothesis. Bioessays 2013, 35, 794-803. [CrossRef]

9. Andreadis, S.; Palsson, B.O. Coupled effects of polybrene and calf serum on the efficiency of retroviral transduction and the stability of retroviral vectors. Hum. Gene Ther. 1997, 8, 285-291. [CrossRef]

10. Lewis, P.F.; Emerman, M. Passage through mitosis is required for oncoretroviruses but not for the human immunodeficiency virus. J. Virol. 1994, 68, 510-516. [CrossRef]

11. Ryser, M.F.; Roesler, J.; Gentsch, M.; Brenner, S. Gene therapy for chronic granulomatous disease. Expert Opin. Biol. Ther. 2007, 7, 1799-1809. [CrossRef] [PubMed]

12. Le Doux, J.M.; Davis, H.E.; Morgan, J.R.; Yarmush, M.L. Kinetics of retrovirus production and decay. Biotechnol. Bioeng. 1999, 63, 654-662. [CrossRef]

13. Howe, S.J.; Mansour, M.R.; Schwarzwaelder, K.; Bartholomae, C.; Hubank, M.; Kempski, H.; Brugman, M.H.; Pike-Overzet, K.; Chatters, S.J.; de Ridder, D.; et al. Insertional mutagenesis combined with acquired somatic mutations causes leukemogenesis following gene therapy of SCID-X1 patients. J. Clin. Investig. 2008, 118, 3143-3150. [CrossRef] [PubMed]

14. Kustikova, O.S.; Schiedlmeier, B.; Brugman, M.H.; Stahlhut, M.; Bartels, S.; Li, Z.; Baum, C. Cell-intrinsic and vector-related properties cooperate to determine the incidence and consequences of insertional mutagenesis. Mol. Ther. 2009, 17, 1537-1547. [CrossRef]

15. Modlich, U.; Bohne, J.; Schmidt, M.; von Kalle, C.; Knöss, S.; Schambach, A.; Baum, C. Cell-culture assays reveal the importance of retroviral vector design for insertional genotoxicity. Blood 2006, 108, 2545-2553. [CrossRef] 
16. Kafri, T.; van Praag, H.; Ouyang, L.; Gage, F.H.; Verma, I.M. A packaging cell line for lentivirus vectors. J. Virol. 1999, 73, 576-584. [CrossRef]

17. Akkina, R.K.; Walton, R.M.; Chen, M.L.; Li, Q.X.; Planelles, V.; Chen, I.S. High-efficiency gene transfer into $\mathrm{CD} 34^{+}$cells with a human immunodeficiency virus type 1-based retroviral vector pseudotyped with vesicular stomatitis virus envelope glycoprotein G. J. Virol. 1996, 70, 2581-2585. [CrossRef]

18. DePolo, N.J.; Reed, J.D.; Sheridan, P.L.; Townsend, K.; Sauter, S.L.; Jolly, D.J.; Dubensky, T.W. VSV-G pseudotyped lentiviral vector particles produced in human cells are inactivated by human serum. Mol. Ther. 2000, 2, 218-222. [CrossRef]

19. Hu, S.; Mohan Kumar, D.; Sax, C.; Schuler, C.; Akkina, R. Pseudotyping of lentiviral vector with novel vesiculovirus envelope glycoproteins derived from Chandipura and Piry viruses. Virology 2016, 488, 162-168. [CrossRef]

20. Milani, M.; Annoni, A.; Moalli, F.; Liu, T.; Cesana, D.; Calabria, A.; Bartolaccini, S.; Biffi, M.; Russo, F.; Visigalli, I.; et al. Phagocytosis-shielded lentiviral vectors improve liver gene therapy in nonhuman primates. Sci. Transl. Med. 2019, 11. [CrossRef]

21. Mátrai, J.; Cantore, A.; Bartholomae, C.C.; Annoni, A.; Wang, W.; Acosta-Sanchez, A.; Samara-Kuko, E.; De Waele, L.; Ma, L.; Genovese, P.; et al. Hepatocyte-targeted expression by integrase-defective lentiviral vectors induces antigen-specific tolerance in mice with low genotoxic risk. Hepatology 2011, 53, 1696-1707. [CrossRef] [PubMed]

22. Kennedy, E.M.; Bassit, L.C.; Mueller, H.; Kornepati, A.V.R.; Bogerd, H.P.; Nie, T.; Chatterjee, P.; Javanbakht, H.; Schinazi, R.F.; Cullen, B.R. Suppression of hepatitis B virus DNA accumulation in chronically infected cells using a bacterial CRISPR/Cas RNA-guided DNA endonuclease. Virology 2015, 476, 196-205. [CrossRef] [PubMed]

23. Liu, X.; Hao, R.; Chen, S.; Guo, D.; Chen, Y. Inhibition of hepatitis B virus by the CRISPR/Cas9 system via targeting the conserved regions of the viral genome. J. Gen. Virol. 2015, 96, 2252-2261. [CrossRef] [PubMed]

24. Ehrhardt, A.; Kay, M.A. A new adenoviral helper-dependent vector results in long-term therapeutic levels of human coagulation factor IX at low doses in vivo. Blood 2002, 99, 3923-3930. [CrossRef]

25. Ehrhardt, A.; Xu, H.; Kay, M.A. Episomal persistence of recombinant adenoviral vector genomes during the cell cycle in vivo. J. Virol. 2003, 77, 7689-7695. [CrossRef]

26. Schmitt, F.; Pastore, N.; Abarrategui-Pontes, C.; Flageul, M.; Myara, A.; Laplanche, S.; Labrune, P.; Podevin, G.; Nguyen, T.H.; Brunetti-Pierri, N. Correction of hyperbilirubinemia in Gunn rats by surgical delivery of low doses of helper-dependent adenoviral vectors. Hum. Gene Ther. Methods 2014, 25, 181-186. [CrossRef]

27. Marrone, J.; Lehmann, G.L.; Soria, L.R.; Pellegrino, J.M.; Molinas, S.; Marinelli, R.A. Adenoviral transfer of human aquaporin-1 gene to rat liver improves bile flow in estrogen-induced cholestasis. Gene Ther. 2014, 21, 1058-1064. [CrossRef]

28. Jiang, X.; Jiang, L.; Shan, A.; Su, Y.; Cheng, Y.; Song, D.; Ji, H.; Ning, G.; Wang, W.; Cao, Y. Targeting hepatic miR-221/222 for therapeutic intervention of nonalcoholic steatohepatitis in mice. EBioMedicine 2018, 37, 307-321. [CrossRef]

29. Casimiro, D.R.; Chen, L.; Fu, T.M.; Evans, R.K.; Caulfield, M.J.; Davies, M.E.; Tang, A.; Chen, M.; Huang, L.; Harris, V.; et al. Comparative immunogenicity in rhesus monkeys of DNA plasmid, recombinant vaccinia virus, and replication-defective adenovirus vectors expressing a human immunodeficiency virus type 1 gag gene. J. Virol. 2003, 77, 6305-6313. [CrossRef]

30. Casimiro, D.R.; Bett, A.J.; Fu, T.M.; Davies, M.E.; Tang, A.; Wilson, K.A.; Chen, M.; Long, R.; McKelvey, T.; Chastain, M.; et al. Heterologous human immunodeficiency virus type 1 priming-boosting immunization strategies involving replication-defective adenovirus and poxvirus vaccine vectors. J. Virol. 2004, 78, 11434-11438. [CrossRef]

31. Yang, Y.; Li, Q.; Ertl, H.C.; Wilson, J.M. Cellular and humoral immune responses to viral antigens create barriers to lung-directed gene therapy with recombinant adenoviruses. J. Virol. 1995, 69, 2004-2015. [CrossRef] [PubMed]

32. Morral, N.; O’Neal, W.; Rice, K.; Leland, M.; Kaplan, J.; Piedra, P.A.; Zhou, H.; Parks, R.J.; Velji, R.; Aguilar-Córdova, E.; et al. Administration of helper-dependent adenoviral vectors and sequential delivery of different vector serotype for long-term liver-directed gene transfer in baboons. Proc. Natl. Acad. Sci. USA 1999, 96, 12816-12821. [CrossRef] [PubMed] 
33. Mitani, K.; Graham, F.L.; Caskey, C.T.; Kochanek, S. Rescue, propagation, and partial purification of a helper virus-dependent adenovirus vector. Proc. Natl. Acad. Sci. USA 1995, 92, 3854-3858. [CrossRef] [PubMed]

34. Morral, N.; Parks, R.J.; Zhou, H.; Langston, C.; Schiedner, G.; Quinones, J.; Graham, F.L.; Kochanek, S.; Beaudet, A.L. High doses of a helper-dependent adenoviral vector yield supraphysiological levels of alpha1-antitrypsin with negligible toxicity. Hum. Gene Ther. 1998, 9, 2709-2716. [CrossRef]

35. Harui, A.; Suzuki, S.; Kochanek, S.; Mitani, K. Frequency and stability of chromosomal integration of adenovirus vectors. J. Virol. 1999, 73, 6141-6146. [CrossRef]

36. Ross, P.J.; Kennedy, M.A.; Parks, R.J. Host cell detection of noncoding stuffer DNA contained in helper-dependent adenovirus vectors leads to epigenetic repression of transgene expression. J. Virol. 2009, 83, 8409-8417. [CrossRef]

37. Alba, R.; Bosch, A.; Chillon, M. Gutless adenovirus: Last-generation adenovirus for gene therapy. Gene Ther. 2005, 12 (Suppl. 1), S18-S27. [CrossRef]

38. Ledgerwood, J.E.; DeZure, A.D.; Stanley, D.A.; Coates, E.E.; Novik, L.; Enama, M.E.; Berkowitz, N.M.; Hu, Z.; Joshi, G.; Ploquin, A.; et al. Chimpanzee adenovirus vector Ebola vaccine. N. Engl. J. Med. 2017, 376, 928-938. [CrossRef]

39. Hausl, M.A.; Zhang, W.; Müther, N.; Rauschhuber, C.; Franck, H.G.; Merricks, E.P.; Nichols, T.C.; Kay, M.A.; Ehrhardt, A. Hyperactive Sleeping Beauty transposase enables persistent phenotypic correction in mice and a canine model for hemophilia B. Mol. Ther. 2010, 18, 1896-1906. [CrossRef]

40. Hausl, M.; Zhang, W.; Voigtländer, R.; Müther, N.; Rauschhuber, C.; Ehrhardt, A. Development of adenovirus hybrid vectors for Sleeping Beauty transposition in large mammals. Curr. Gene Ther. 2011, 11, 363-374. [CrossRef]

41. Castello, R.; Borzone, R.; D'Aria, S.; Annunziata, P.; Piccolo, P.; Brunetti-Pierri, N. Helper-dependent adenoviral vectors for liver-directed gene therapy of primary hyperoxaluria type 1. Gene Ther. 2016, 23, 129-134. [CrossRef] [PubMed]

42. Daya, S.; Berns, K.I. Gene therapy using adeno-associated virus vectors. Clin. Microbiol. Rev. 2008, 21, 583-593. [CrossRef] [PubMed]

43. Kotin, R.M.; Siniscalco, M.; Samulski, R.J.; Zhu, X.D.; Hunter, L.; Laughlin, C.A.; McLaughlin, S.; Muzyczka, N.; Rocchi, M.; Berns, K.I. Site-specific integration by adeno-associated virus. Proc. Natl. Acad. Sci. USA 1990, 87, 2211-2215. [CrossRef] [PubMed]

44. Boutin, S.; Monteilhet, V.; Veron, P.; Leborgne, C.; Benveniste, O.; Montus, M.F.; Masurier, C. Prevalence of serum IgG and neutralizing factors against adeno-associated virus (AAV) types 1, 2, 5, 6, 8, and 9 in the healthy population: Implications for gene therapy using AAV vectors. Hum. Gene Ther. 2010, 21, 704-712. [CrossRef] [PubMed]

45. Rangarajan, S.; Walsh, L.; Lester, W.; Perry, D.; Madan, B.; Laffan, M.; Yu, H.; Vettermann, C.; Pierce, G.F.; Wong, W.Y.; et al. AAV5-Factor VIII gene transfer in severe hemophilia A. N. Engl. J. Med. 2017, 377, 2519-2530. [CrossRef]

46. Ellis, B.L.; Hirsch, M.L.; Barker, J.C.; Connelly, J.P.; Steininger, R.J.; Porteus, M.H. A survey of ex vivo/in vitro transduction efficiency of mammalian primary cells and cell lines with nine natural adeno-associated virus (AAV1-9) and one engineered adeno-associated virus serotype. Virol. J. 2013, 10, 74. [CrossRef]

47. Ling, C.; Wang, Y.; Zhang, Y.; Ejjigani, A.; Yin, Z.; Lu, Y.; Wang, L.; Wang, M.; Li, J.; Hu, Z.; et al. Selective in vivo targeting of human liver tumors by optimized AAV3 vectors in a murine xenograft model. Hum. Gene Ther. 2014, 25, 1023-1034. [CrossRef]

48. Nakai, H.; Yant, S.R.; Storm, T.A.; Fuess, S.; Meuse, L.; Kay, M.A. Extrachromosomal recombinant adeno-associated virus vector genomes are primarily responsible for stable liver transduction in vivo. J. Virol. 2001, 75, 6969-6976. [CrossRef]

49. Grimm, D.; Lee, J.S.; Wang, L.; Desai, T.; Akache, B.; Storm, T.A.; Kay, M.A. In vitro and in vivo gene therapy vector evolution via multispecies interbreeding and retargeting of adeno-associated viruses. J. Virol. 2008, 82, 5887-5911. [CrossRef]

50. Lisowski, L.; Dane, A.P.; Chu, K.; Zhang, Y.; Cunningham, S.C.; Wilson, E.M.; Nygaard, S.; Grompe, M.; Alexander, I.E.; Kay, M.A. Selection and evaluation of clinically relevant AAV variants in a xenograft liver model. Nature 2014, 506, 382-386. [CrossRef]

51. Donsante, A.; Miller, D.G.; Li, Y.; Vogler, C.; Brunt, E.M.; Russell, D.W.; Sands, M.S. AAV vector integration sites in mouse hepatocellular carcinoma. Science 2007, 317, 477. [CrossRef] [PubMed] 
52. Nault, J.C.; Datta, S.; Imbeaud, S.; Franconi, A.; Mallet, M.; Couchy, G.; Letouzé, E.; Pilati, C.; Verret, B.; Blanc, J.F.; et al. Recurrent AAV2-related insertional mutagenesis in human hepatocellular carcinomas. Nat. Genet. 2015, 47, 1187-1193. [CrossRef] [PubMed]

53. Berns, K.I.; Byrne, B.J.; Flotte, T.R.; Gao, G.; Hauswirth, W.W.; Herzog, R.W.; Muzyczka, N.; Vanden Driessche, T.; Xiao, X.; Zolotukhin, S.; et al. Adeno-associated virus type 2 and hepatocellular carcinoma? Hum. Gene Ther. 2015, 26, 779-781. [CrossRef]

54. Büning, H.; Schmidt, M. Adeno-associated vector toxicity-to be or not to be? Mol. Ther. 2015, 23, 1673-1675. [CrossRef]

55. Park, K.J.; Lee, J.; Park, J.H.; Joh, J.W.; Kwon, C.H.; Kim, J.W. Adeno-associated virus 2-mediated hepatocellular carcinoma is very rare in Korean patients. Ann. Lab. Med. 2016, 36, 469-474. [CrossRef]

56. La Bella, T.; Imbeaud, S.; Peneau, C.; Mami, I.; Datta, S.; Bayard, Q.; Caruso, S.; Hirsch, T.Z.; Calderaro, J.; Morcrette, G.; et al. Adeno-associated virus in the liver: Natural history and consequences in tumour development. Gut 2020, 69, 737-747. [CrossRef] [PubMed]

57. Nault, J.C.; Mami, I.; La Bella, T.; Datta, S.; Imbeaud, S.; Franconi, A.; Mallet, M.; Couchy, G.; Letouzé, E.; Pilati, C.; et al. Wild-type AAV insertions in hepatocellular carcinoma do not inform debate over genotoxicity risk of vectorized AAV. Mol. Ther. 2016, 24, 660-661. [CrossRef] [PubMed]

58. Murillo, O.; Luqui, D.M.; Gazquez, C.; Martinez-Espartosa, D.; Navarro-Blasco, I.; Monreal, J.I.; Guembe, L.; Moreno-Cermeño, A.; Corrales, F.J.; Prieto, J.; et al. Long-term metabolic correction of Wilson's disease in a murine model by gene therapy. J. Hepatol. 2016, 64, 419-426. [CrossRef]

59. Yasuda, M.; Bishop, D.F.; Fowkes, M.; Cheng, S.H.; Gan, L.; Desnick, R.J. AAV8-mediated gene therapy prevents induced biochemical attacks of acute intermittent porphyria and improves neuromotor function. Mol. Ther. 2010, 18, 17-22. [CrossRef]

60. Unzu, C.; Sampedro, A.; Mauleón, I.; Alegre, M.; Beattie, S.G.; de Salamanca, R.E.; Snapper, J.; Twisk, J.; Petry, H.; González-Aseguinolaza, G.; et al. Sustained enzymatic correction by rAAV-mediated liver gene therapy protects against induced motor neuropathy in acute porphyria mice. Mol. Ther. 2011, 19, $243-250$. [CrossRef]

61. Guenzel, A.J.; Collard, R.; Kraus, J.P.; Matern, D.; Barry, M.A. Long-term sex-biased correction of circulating propionic acidemia disease markers by adeno-associated virus vectors. Hum. Gene Ther. 2015, 26, 153-160. [CrossRef] [PubMed]

62. Chandler, R.J.; Venditti, C.P. Pre-clinical efficacy and dosing of an AAV8 vector expressing human methylmalonyl-CoA mutase in a murine model of methylmalonic acidemia (MMA). Mol. Genet. Metab. 2012, 107, 617-619. [CrossRef] [PubMed]

63. Yagi, H.; Ogura, T.; Mizukami, H.; Urabe, M.; Hamada, H.; Yoshikawa, H.; Ozawa, K.; Kume, A. Complete restoration of phenylalanine oxidation in phenylketonuria mouse by a self-complementary adeno-associated virus vector. J. Gene Med. 2011, 13, 114-122. [CrossRef] [PubMed]

64. Yiu, W.H.; Lee, Y.M.; Peng, W.T.; Pan, C.J.; Mead, P.A.; Mansfield, B.C.; Chou, J.Y. Complete normalization of hepatic G6PC deficiency in murine glycogen storage disease type Ia using gene therapy. Mol. Ther. 2010, 18, 1076-1084. [CrossRef]

65. Weinstein, D.A.; Correia, C.E.; Conlon, T.; Specht, A.; Verstegen, J.; Onclin-Verstegen, K.; Campbell-Thompson, M.; Dhaliwal, G.; Mirian, L.; Cossette, H.; et al. Adeno-associated virus-mediated correction of a canine model of glycogen storage disease type Ia. Hum. Gene Ther. 2010, 21, 903-910. [CrossRef]

66. Aronson, S.J.; Bakker, R.S.; Shi, X.; Duijst, S.; Ten Bloemendaal, L.; de Waart, D.R.; Verheij, J.; Ronzitti, G.; Oude Elferink, R.P.; Beuers, U.; et al. Liver-directed gene therapy results in long-term correction of progressive familial intrahepatic cholestasis type 3 in mice. J. Hepatol. 2019, 71, 153-162. [CrossRef]

67. Sabatino, D.E.; Lange, A.M.; Altynova, E.S.; Sarkar, R.; Zhou, S.; Merricks, E.P.; Franck, H.G.; Nichols, T.C.; Arruda, V.R.; Kazazian, H.H. Efficacy and safety of long-term prophylaxis in severe hemophilia A dogs following liver gene therapy using AAV vectors. Mol. Ther. 2011, 19, 442-449. [CrossRef]

68. Nguyen, G.N.; Everett, J.K.; Raymond, H.; Kafle, S.; Merricks, E.P.; Kazazian, H.H.; Nichols, T.C.; Bushman, F.D.; Sabatino, D.E. Long-term AAV-mediated factor VIII expression in nine hemophilia A dogs: A 10 year follow-up analysis on durability, safety and vector integration. Blood 2019, 134, 611. [CrossRef] 
69. Nathwani, A.C.; Tuddenham, E.G.; Rangarajan, S.; Rosales, C.; McIntosh, J.; Linch, D.C.; Chowdary, P.; Riddell, A.; Pie, A.J.; Harrington, C.; et al. Adenovirus-associated virus vector-mediated gene transfer in hemophilia B. N. Engl. J. Med. 2011, 365, 2357-2365. [CrossRef]

70. George, L.A.; Sullivan, S.K.; Giermasz, A.; Rasko, J.E.J.; Samelson-Jones, B.J.; Ducore, J.; Cuker, A.; Sullivan, L.M.; Majumdar, S.; Teitel, J.; et al. Hemophilia B gene therapy with a high-specific-activity factor IX variant. N. Engl. J. Med. 2017, 377, 2215-2227. [CrossRef]

71. Pasi, K.J.; Rangarajan, S.; Mitchell, N.; Lester, W.; Symington, E.; Madan, B.; Laffan, M.; Russell, C.B.; Li, M.; Pierce, G.F.; et al. Multiyear follow-up of AAV5-hFVIII-SQ gene therapy for hemophilia A. N. Engl. J. Med. 2020, 382, 29-40. [CrossRef] [PubMed]

72. D'Avola, D.; López-Franco, E.; Sangro, B.; Pañeda, A.; Grossios, N.; Gil-Farina, I.; Benito, A.; Twisk, J.; Paz, M.; Ruiz, J.; et al. Phase I open label liver-directed gene therapy clinical trial for acute intermittent porphyria. J. Hepatol. 2016, 65, 776-783. [CrossRef] [PubMed]

73. Russell, S.; Bennett, J.; Wellman, J.A.; Chung, D.C.; Yu, Z.F.; Tillman, A.; Wittes, J.; Pappas, J.; Elci, O.; McCague, S.; et al. Efficacy and safety of voretigene neparvovec (AAV2-hRPE65v2) in patients with RPE65-mediated inherited retinal dystrophy: A randomised, controlled, open-label, phase 3 trial. Lancet 2017, 390, 849-860. [CrossRef]

74. Day, J.W.; Chiriboga, C.A.; Crawford, T.O.; Darras, B.T.; Finkel, R.S.; Connolly, A.M.; Iannaccone, S.T.; Kuntz, N.L.; Peña, L.D.M.; Shieh, P.B.; et al. Onasemnogene abeparvovec-xioi gene-replacement therapy for spinal muscular atrophy type 1 (SMA1): Phase 3 US study (STR1VE) update (1828). Neurology 2020, $94,1828$.

75. Manno, C.S.; Pierce, G.F.; Arruda, V.R.; Glader, B.; Ragni, M.; Rasko, J.J.; Rasko, J.; Ozelo, M.C.; Hoots, K.; Blatt, P.; et al. Successful transduction of liver in hemophilia by AAV-Factor IX and limitations imposed by the host immune response. Nat. Med. 2006, 12, 342-347. [CrossRef]

76. Arruda, V.R.; Stedman, H.H.; Haurigot, V.; Buchlis, G.; Baila, S.; Favaro, P.; Chen, Y.; Franck, H.G.; Zhou, S.; Wright, J.F.; et al. Peripheral transvenular delivery of adeno-associated viral vectors to skeletal muscle as a novel therapy for hemophilia B. Blood 2010, 115, 4678-4688. [CrossRef]

77. Haurigot, V.; Mingozzi, F.; Buchlis, G.; Hui, D.J.; Chen, Y.; Basner-Tschakarjan, E.; Arruda, V.R.; Radu, A.; Franck, H.G.; Wright, J.F.; et al. Safety of AAV factor IX peripheral transvenular gene delivery to muscle in hemophilia B dogs. Mol. Ther. 2010, 18, 1318-1329. [CrossRef]

78. Jiang, H.; Couto, L.B.; Patarroyo-White, S.; Liu, T.; Nagy, D.; Vargas, J.A.; Zhou, S.; Scallan, C.D.; Sommer, J.; Vijay, S.; et al. Effects of transient immunosuppression on adenoassociated, virus-mediated, liver-directed gene transfer in rhesus macaques and implications for human gene therapy. Blood 2006, 108, 3321-3328. [CrossRef]

79. Scallan, C.D.; Jiang, H.; Liu, T.; Patarroyo-White, S.; Sommer, J.M.; Zhou, S.; Couto, L.B.; Pierce, G.F. Human immunoglobulin inhibits liver transduction by AAV vectors at low AAV2 neutralizing titers in SCID mice. Blood 2006, 107, 1810-1817. [CrossRef]

80. Sowd, G.A.; Fanning, E. A wolf in sheep's clothing: SV40 co-opts host genome maintenance proteins to replicate viral DNA. PLoS Pathog. 2012, 8, e1002994. [CrossRef]

81. Strayer, D.; Branco, F.; Zern, M.A.; Yam, P.; Calarota, S.A.; Nichols, C.N.; Zaia, J.A.; Rossi, J.; Li, H.; Parashar, B.; et al. Durability of transgene expression and vector integration: Recombinant SV40-derived gene therapy vectors. Mol. Ther. 2002, 6, 227-237. [CrossRef] [PubMed]

82. Sauter, B.V.; Parashar, B.; Chowdhury, N.R.; Kadakol, A.; Ilan, Y.; Singh, H.; Milano, J.; Strayer, D.S.; Chowdhury, J.R. A replication-deficient rSV40 mediates liver-directed gene transfer and a long-term amelioration of jaundice in Gunn rats. Gastroenterology 2000, 119, 1348-1357. [CrossRef] [PubMed]

83. Vera, M.; Prieto, J.; Strayer, D.S.; Fortes, P. Factors influencing the production of recombinant SV 40 vectors. Mol. Ther. 2004, 10, 780-791. [CrossRef] [PubMed]

84. Fahrbach, K.M.; Katzman, R.B.; Rundell, K. Role of SV40 ST antigen in the persistent infection of mesothelial cells. Virology 2008, 370, 255-263. [CrossRef]

85. Toscano, M.G.; van der Velden, J.; van der Werf, S.; Odijk, M.; Roque, A.; Camacho-Garcia, R.J.; Herrera-Gomez, I.G.; Mancini, I.; de Haan, P. Generation of a Vero-based packaging cell line to produce SV40 gene delivery vectors for use in clinical gene therapy studies. Mol. Ther. Methods Clin. Dev. 2017, 6, 124-134. [CrossRef] [PubMed]

86. Johnson, G.T.; Autin, L.; Al-Alusi, M.; Goodsell, D.S.; Sanner, M.F.; Olson, A.J. cellPACK: A virtual mesoscope to model and visualize structural systems biology. Nat. Methods 2015, 12, 85-91. [CrossRef] [PubMed] 
87. Wu, H.; Kwong, P.D.; Hendrickson, W.A. Dimeric association and segmental variability in the structure of human CD4. Nature 1997, 387, 527-530. [CrossRef] [PubMed]

88. Flatt, J.W.; Kim, R.; Smith, J.G.; Nemerow, G.R.; Stewart, P.L. An intrinsically disordered region of the adenovirus capsid is implicated in neutralization by human alpha defensin 5. PLoS ONE 2013, 8, e61571. [CrossRef] [PubMed]

89. Patzke, C.; Max, K.E.; Behlke, J.; Schreiber, J.; Schmidt, H.; Dorner, A.A.; Kröger, S.; Henning, M.; Otto, A.; Heinemann, U.; et al. The coxsackievirus-adenovirus receptor reveals complex homophilic and heterophilic interactions on neural cells. J. Neurosci. 2010, 30, 2897-2910. [CrossRef] [PubMed]

90. Shayakhmetov, D.M.; Gaggar, A.; Ni, S.; Li, Z.Y.; Lieber, A. Adenovirus binding to blood factors results in liver cell infection and hepatotoxicity. J. Virol. 2005, 79, 7478-7491. [CrossRef]

91. Tan, Y.Z.; Aiyer, S.; Mietzsch, M.; Hull, J.A.; McKenna, R.; Grieger, J.; Samulski, R.J.; Baker, T.S.; Agbandje-McKenna, M.; Lyumkis, D. Sub-2 Å Ewald curvature corrected structure of an AAV2 capsid variant. Nat. Commun. 2018, 9, 3628. [CrossRef]

92. Meyer, N.L.; Hu, G.; Davulcu, O.; Xie, Q.; Noble, A.J.; Yoshioka, C.; Gingerich, D.S.; Trzynka, A.; David, L.; Stagg, S.M.; et al. Structure of the gene therapy vector, adeno-associated virus with its cell receptor, AAVR. Elife 2019, 8. [CrossRef] [PubMed]

93. Dudek, A.M.; Zabaleta, N.; Zinn, E.; Pillay, S.; Zengel, J.; Porter, C.; Franceschini, J.S.; Estelien, R.; Carette, J.E.; Zhou, G.L.; et al. GPR108 is a highly conserved AAV entry factor. Mol. Ther. 2020, 28, 367-381. [CrossRef] [PubMed]

94. Shen, P.S.; Enderlein, D.; Nelson, C.D.; Carter, W.S.; Kawano, M.; Xing, L.; Swenson, R.D.; Olson, N.H.; Baker, T.S.; Cheng, R.H.; et al. The structure of avian polyomavirus reveals variably sized capsids, non-conserved inter-capsomere interactions, and a possible location of the minor capsid protein VP4. Virology 2011, 411, 142-152. [CrossRef]

95. Neu, U.; Woellner, K.; Gauglitz, G.; Stehle, T. Structural basis of GM1 ganglioside recognition by simian virus 40. Proc. Natl. Acad. Sci. USA 2008, 105, 5219-5224. [CrossRef] [PubMed]

96. Pettersen, E.F.; Goddard, T.D.; Huang, C.C.; Couch, G.S.; Greenblatt, D.M.; Meng, E.C.; Ferrin, T.E. UCSF Chimera-A visualization system for exploratory research and analysis. J. Comput. Chem. 2004, 25, 1605-1612. [CrossRef] [PubMed]

97. Ivics, Z.; Hackett, P.B.; Plasterk, R.H.; Izsvák, Z. Molecular reconstruction of Sleeping Beauty, a Tc1-like transposon from fish, and its transposition in human cells. Cell 1997, 91, 501-510. [CrossRef]

98. Aronovich, E.L.; McIvor, R.S.; Hackett, P.B. The Sleeping Beauty transposon system: A non-viral vector for gene therapy. Hum. Mol. Genet. 2011, 20, R14-R20. [CrossRef]

99. Vigdal, T.J.; Kaufman, C.D.; Izsvák, Z.; Voytas, D.F.; Ivics, Z. Common physical properties of DNA affecting target site selection of Sleeping Beauty and other Tc1/mariner transposable elements. J. Mol. Biol. 2002, 323, 441-452. [CrossRef]

100. Liu, G.; Geurts, A.M.; Yae, K.; Srinivasan, A.R.; Fahrenkrug, S.C.; Largaespada, D.A.; Takeda, J.; Horie, K.; Olson, W.K.; Hackett, P.B. Target-site preferences of Sleeping Beauty transposons. J. Mol. Biol. 2005, 346, 161-173. [CrossRef]

101. Gogol-Döring, A.; Ammar, I.; Gupta, S.; Bunse, M.; Miskey, C.; Chen, W.; Uckert, W.; Schulz, T.F.; Izsvák, Z.; Ivics, Z. Genome-wide profiling reveals remarkable parallels between insertion site selection properties of the MLV retrovirus and the piggyBac transposon in primary human CD4(+) T cells. Mol. Ther. 2016, 24, 592-606. [CrossRef]

102. Fernando, S.; Fletcher, B.S. Sleeping Beauty transposon-mediated nonviral gene therapy. BioDrugs 2006, 20, 219-229. [CrossRef]

103. Hackett, P.B.; Largaespada, D.A.; Cooper, L.J. A transposon and transposase system for human application. Mol. Ther. 2010, 18, 674-683. [CrossRef] [PubMed]

104. Ivics, Z.; Izsvák, Z. Transposons for gene therapy! Curr. Gene Ther. 2006, 6, 593-607. [CrossRef] [PubMed]

105. Izsvák, Z.; Hackett, P.B.; Cooper, L.J.; Ivics, Z. Translating Sleeping Beauty transposition into cellular therapies: Victories and challenges. Bioessays 2010, 32, 756-767. [CrossRef] [PubMed]

106. Loeb, K.R.; Hughes, B.T.; Fissel, B.M.; Osteen, N.J.; Knoblaugh, S.E.; Grim, J.E.; Drury, L.J.; Sarver, A.; Dupuy, A.J.; Clurman, B.E. Insertional mutagenesis using the Sleeping Beauty transposon system identifies drivers of erythroleukemia in mice. Sci. Rep. 2019, 9, 5488. [CrossRef] 
107. Hackett, P.B.; Largaespada, D.A.; Switzer, K.C.; Cooper, L.J. Evaluating risks of insertional mutagenesis by DNA transposons in gene therapy. Transl. Res. 2013, 161, 265-283. [CrossRef]

108. Aravalli, R.N.; Belcher, J.D.; Steer, C.J. Liver-targeted gene therapy: Approaches and challenges. Liver Transpl. 2015, 21, 718-737. [CrossRef]

109. Aravalli, R.N.; Steer, C.J. Gene editing technology as an approach to the treatment of liver diseases. Expert Opin. Biol. Ther. 2016, 16, 595-608. [CrossRef]

110. Zabaleta, N.; Hommel, M.; Salas, D.; Gonzalez-Aseguinolaza, G. Genetic-based approaches to inherited metabolic liver diseases. Hum. Gene Ther. 2019, 30, 1190-1203. [CrossRef]

111. Turunen, T.A.; Kurkipuro, J.; Heikura, T.; Vuorio, T.; Hytönen, E.; Izsvák, Z.; Ylä-Herttuala, S. Sleeping Beauty transposon vectors in liver-directed gene delivery of LDLR and VLDLR for gene therapy of familial hypercholesterolemia. Mol. Ther. 2016, 24, 620-635. [CrossRef] [PubMed]

112. Portier, I.; Vanhoorelbeke, K.; Verhenne, S.; Pareyn, I.; Vandeputte, N.; Deckmyn, H.; Goldenberg, D.S.; Samal, H.B.; Singh, M.; Ivics, Z.; et al. High and long-term von Willebrand factor expression after Sleeping Beauty transposon-mediated gene therapy in a mouse model of severe von Willebrand disease. J. Thromb. Haemost. 2018, 16, 592-604. [CrossRef] [PubMed]

113. Fraser, M.J.; Smith, G.E.; Summers, M.D. Acquisition of host cell DNA sequences by baculoviruses: Relationship between host DNA insertions and FP mutants of Autographa californica and Galleria mellonella nuclear polyhedrosis viruses. J. Virol. 1983, 47, 287-300. [CrossRef] [PubMed]

114. Cary, L.C.; Goebel, M.; Corsaro, B.G.; Wang, H.G.; Rosen, E.; Fraser, M.J. Transposon mutagenesis of baculoviruses: Analysis of Trichoplusia ni transposon IFP2 insertions within the FP-locus of nuclear polyhedrosis viruses. Virology 1989, 172, 156-169. [CrossRef]

115. Li, M.A.; Turner, D.J.; Ning, Z.; Yusa, K.; Liang, Q.; Eckert, S.; Rad, L.; Fitzgerald, T.W.; Craig, N.L.; Bradley, A. Mobilization of giant piggyBac transposons in the mouse genome. Nucleic Acids Res. 2011, 39, e148. [CrossRef]

116. Elick, T.A.; Bauser, C.A.; Fraser, M.J. Excision of the piggyBac transposable element in vitro is a precise event that is enhanced by the expression of its encoded transposase. Genetica 1996, 98, 33-41. [CrossRef]

117. Saridey, S.K.; Liu, L.; Doherty, J.E.; Kaja, A.; Galvan, D.L.; Fletcher, B.S.; Wilson, M.H. PiggyBac transposon-based inducible gene expression in vivo after somatic cell gene transfer. Mol. Ther. 2009, 17, 2115-2120. [CrossRef]

118. Nakanishi, H.; Higuchi, Y.; Kawakami, S.; Yamashita, F.; Hashida, M. PiggyBac transposon-mediated long-term gene expression in mice. Mol. Ther. 2010, 18, 707-714. [CrossRef]

119. Matsui, H.; Fujimoto, N.; Sasakawa, N.; Ohinata, Y.; Shima, M.; Yamanaka, S.; Sugimoto, M.; Hotta, A. Delivery of full-length factor VIII using a piggyBac transposon vector to correct a mouse model of hemophilia A. PLoS ONE 2014, 9, e104957. [CrossRef]

120. Di Matteo, M.; Samara-Kuko, E.; Ward, N.J.; Waddington, S.N.; Waddingon, S.N.; McVey, J.H.; Chuah, M.K.; VandenDriessche, T. Hyperactive piggyBac transposons for sustained and robust liver-targeted gene therapy. Mol. Ther. 2014, 22, 1614-1624. [CrossRef]

121. Huang, X.; Guo, H.; Tammana, S.; Jung, Y.C.; Mellgren, E.; Bassi, P.; Cao, Q.; Tu, Z.J.; Kim, Y.C.; Ekker, S.C.; et al. Gene transfer efficiency and genome-wide integration profiling of Sleeping Beauty, Tol2, and piggyBac transposons in human primary T cells. Mol. Ther. 2010, 18, 1803-1813. [CrossRef] [PubMed]

122. Mehier-Humbert, S.; Guy, R.H. Physical methods for gene transfer: Improving the kinetics of gene delivery into cells. Adv. Drug Deliv. Rev. 2005, 57, 733-753. [CrossRef] [PubMed]

123. Wells, D.J. Gene therapy progress and prospects: Electroporation and other physical methods. Gene Ther. 2004, 11, 1363-1369. [CrossRef] [PubMed]

124. Newman, C.M.; Bettinger, T. Gene therapy progress and prospects: Ultrasound for gene transfer. Gene Ther. 2007, 14, 465-475. [CrossRef]

125. Plank, C.; Schillinger, U.; Scherer, F.; Bergemann, C.; Rémy, J.S.; Krötz, F.; Anton, M.; Lausier, J.; Rosenecker, J. The magnetofection method: Using magnetic force to enhance gene delivery. Biol. Chem. 2003, 384, 737-747. [CrossRef]

126. Zhang, G.; Budker, V.G.; Ludtke, J.J.; Wolff, J.A. Naked DNA gene transfer in mammalian cells. Methods Mol. Biol. 2004, 245, 251-264. [CrossRef]

127. Kawabata, K.; Takakura, Y.; Hashida, M. The fate of plasmid DNA after intravenous injection in mice: Involvement of scavenger receptors in its hepatic uptake. Pharm. Res. 1995, 12, 825-830. [CrossRef]

128. Mintzer, M.A.; Simanek, E.E. Nonviral vectors for gene delivery. Chem. Rev. 2009, 109, 259-302. [CrossRef] 
129. Li, W.; Szoka, F.C. Lipid-based nanoparticles for nucleic acid delivery. Pharm. Res. 2007, 24, 438-449. [CrossRef]

130. Sokolova, V.; Epple, M. Inorganic nanoparticles as carriers of nucleic acids into cells. Angew. Chem. Int. Ed. Engl. 2008, 47, 1382-1395. [CrossRef]

131. Pack, D.W.; Hoffman, A.S.; Pun, S.; Stayton, P.S. Design and development of polymers for gene delivery. Nat. Rev. Drug Discov. 2005, 4, 581-593. [CrossRef] [PubMed]

132. Thomas, M.; Klibanov, A.M. Non-viral gene therapy: Polycation-mediated DNA delivery. Appl. Microbiol. Biotechnol. 2003, 62, 27-34. [CrossRef] [PubMed]

133. Lee, C.C.; MacKay, J.A.; Fréchet, J.M.; Szoka, F.C. Designing dendrimers for biological applications. Nat. Biotechnol. 2005, 23, 1517-1526. [CrossRef] [PubMed]

134. Discher, D.E.; Ahmed, F. Polymersomes. Annu. Rev. Biomed. Eng. 2006, 8, 323-341. [CrossRef]

135. Martin, M.E.; Rice, K.G. Peptide-guided gene delivery. AAPS J. 2007, 9, E18-E29. [CrossRef]

136. Morille, M.; Passirani, C.; Vonarbourg, A.; Clavreul, A.; Benoit, J.P. Progress in developing cationic vectors for non-viral systemic gene therapy against cancer. Biomaterials 2008, 29, 3477-3496. [CrossRef]

137. Cohen, R.N.; van der Aa, M.A.; Macaraeg, N.; Lee, A.P.; Szoka, F.C. Quantification of plasmid DNA copies in the nucleus after lipoplex and polyplex transfection. J. Control. Release 2009, 135, 166-174. [CrossRef]

138. Sardh, E.; Harper, P.; Balwani, M.; Stein, P.; Rees, D.; Bissell, D.M.; Desnick, R.; Parker, C.; Phillips, J.; Bonkovsky, H.L.; et al. Phase 1 trial of an RNA interference therapy for acute intermittent porphyria. $N$. Engl. J. Med. 2019, 380, 549-558. [CrossRef]

139. Adams, D.; Gonzalez-Duarte, A.; O’Riordan, W.D.; Yang, C.C.; Ueda, M.; Kristen, A.V.; Tournev, I.; Schmidt, H.H.; Coelho, T.; Berk, J.L.; et al. Patisiran, an RNAi therapeutic, for hereditary transthyretin amyloidosis. N. Engl. J. Med. 2018, 379, 11-21. [CrossRef]

140. McGregor, T.L.; Hunt, K.A.; Yee, E.; Mason, D.; Nioi, P.; Ticau, S.; Pelosi, M.; Loken, P.R.; Finer, S.; Lawlor, D.A.; et al. Characterising a healthy adult with a rare $H A O 1$ knockout to support a therapeutic strategy for primary hyperoxaluria. Elife 2020, 9. [CrossRef]

141. Machin, N.; Ragni, M.V. An investigational RNAi therapeutic targeting antithrombin for the treatment of hemophilia A and B. J. Blood Med. 2018, 9, 135-140. [CrossRef] [PubMed]

142. Javanbakht, H.; Mueller, H.; Walther, J.; Zhou, X.; Lopez, A.; Pattupara, T.; Blaising, J.; Pedersen, L.; Albæk, N.; Jackerott, M.; et al. Liver-targeted anti-HBV single-stranded oligonucleotides with locked nucleic acid potently reduce HBV gene expression in vivo. Mol. Ther. Nucleic Acids 2018, 11, 441-454. [CrossRef] [PubMed]

143. Truong, B.; Allegri, G.; Liu, X.B.; Burke, K.E.; Zhu, X.; Cederbaum, S.D.; Häberle, J.; Martini, P.G.V.; Lipshutz, G.S. Lipid nanoparticle-targeted mRNA therapy as a treatment for the inherited metabolic liver disorder arginase deficiency. Proc. Natl. Acad. Sci. USA 2019, 116, 21150-21159. [CrossRef] [PubMed]

144. Murakami, Y.; Yasuda, T.; Saigo, K.; Urashima, T.; Toyoda, H.; Okanoue, T.; Shimotohno, K. Comprehensive analysis of microRNA expression patterns in hepatocellular carcinoma and non-tumorous tissues. Oncogene 2006, 25, 2537-2545. [CrossRef]

145. Jiang, J.; Gusev, Y.; Aderca, I.; Mettler, T.A.; Nagorney, D.M.; Brackett, D.J.; Roberts, L.R.; Schmittgen, T.D. Association of microRNA expression in hepatocellular carcinomas with hepatitis infection, cirrhosis, and patient survival. Clin. Cancer Res. 2008, 14, 419-427. [CrossRef]

146. Ura, S.; Honda, M.; Yamashita, T.; Ueda, T.; Takatori, H.; Nishino, R.; Sunakozaka, H.; Sakai, Y.; Horimoto, K.; Kaneko, S. Differential microRNA expression between hepatitis B and hepatitis $\mathrm{C}$ leading disease progression to hepatocellular carcinoma. Hepatology 2009, 49, 1098-1112. [CrossRef]

147. Lagos-Quintana, M.; Rauhut, R.; Yalcin, A.; Meyer, J.; Lendeckel, W.; Tuschl, T. Identification of tissue-specific microRNAs from mouse. Curr. Biol. 2002, 12, 735-739. [CrossRef]

148. Chang, J.; Nicolas, E.; Marks, D.; Sander, C.; Lerro, A.; Buendia, M.A.; Xu, C.; Mason, W.S.; Moloshok, T.; Bort, R.; et al. miR-122, a mammalian liver-specific microRNA, is processed from hor mRNA and may downregulate the high affinity cationic amino acid transporter CAT-1. RNA Biol. 2004, 1, 106-113. [CrossRef]

149. Jopling, C.L.; Yi, M.; Lancaster, A.M.; Lemon, S.M.; Sarnow, P. Modulation of hepatitis C virus RNA abundance by a liver-specific microRNA. Science 2005, 309, 1577-1581. [CrossRef]

150. Esau, C.; Davis, S.; Murray, S.F.; Yu, X.X.; Pandey, S.K.; Pear, M.; Watts, L.; Booten, S.L.; Graham, M.; McKay, R.; et al. miR-122 regulation of lipid metabolism revealed by in vivo antisense targeting. Cell Metab. 2006, 3, 87-98. [CrossRef] 
151. Kutay, H.; Bai, S.; Datta, J.; Motiwala, T.; Pogribny, I.; Frankel, W.; Jacob, S.T.; Ghoshal, K. Downregulation of miR-122 in the rodent and human hepatocellular carcinomas. J. Cell. Biochem. 2006, 99, 671-678. [CrossRef] [PubMed]

152. Tsai, W.C.; Hsu, P.W.; Lai, T.C.; Chau, G.Y.; Lin, C.W.; Chen, C.M.; Lin, C.D.; Liao, Y.L.; Wang, J.L.; Chau, Y.P.; et al. microRNA-122, a tumor suppressor microRNA that regulates intrahepatic metastasis of hepatocellular carcinoma. Hepatology 2009, 49, 1571-1582. [CrossRef] [PubMed]

153. Henke, J.I.; Goergen, D.; Zheng, J.; Song, Y.; Schüttler, C.G.; Fehr, C.; Jünemann, C.; Niepmann, M. microRNA-122 stimulates translation of hepatitis C virus RNA. EMBO J. 2008, 27, 3300-3310. [CrossRef] [PubMed]

154. Kota, J.; Chivukula, R.R.; O’Donnell, K.A.; Wentzel, E.A.; Montgomery, C.L.; Hwang, H.W.; Chang, T.C.; Vivekanandan, P.; Torbenson, M.; Clark, K.R.; et al. Therapeutic microRNA delivery suppresses tumorigenesis in a murine liver cancer model. Cell 2009, 137, 1005-1017. [CrossRef]

155. Fu, Y.; Chen, J.; Huang, Z. Recent progress in microRNA-based delivery systems for the treatment of human disease. ExRNA 2019, 1, 24. [CrossRef]

156. Porteus, M.H.; Carroll, D. Gene targeting using zinc finger nucleases. Nat. Biotechnol. 2005, 23, 967-973. [CrossRef]

157. Li, H.; Haurigot, V.; Doyon, Y.; Li, T.; Wong, S.Y.; Bhagwat, A.S.; Malani, N.; Anguela, X.M.; Sharma, R.; Ivanciu, L.; et al. In vivo genome editing restores haemostasis in a mouse model of haemophilia. Nature 2011, 475, 217-221. [CrossRef]

158. Anguela, X.M.; Sharma, R.; Doyon, Y.; Miller, J.C.; Li, H.; Haurigot, V.; Rohde, M.E.; Wong, S.Y.; Davidson, R.J.; Zhou, S.; et al. Robust ZFN-mediated genome editing in adult hemophilic mice. Blood 2013, 122, 3283-3287. [CrossRef]

159. Sharma, R.; Anguela, X.M.; Doyon, Y.; Wechsler, T.; DeKelver, R.C.; Sproul, S.; Paschon, D.E.; Miller, J.C.; Davidson, R.J.; Shivak, D.; et al. In vivo genome editing of the albumin locus as a platform for protein replacement therapy. Blood 2015, 126, 1777-1784. [CrossRef]

160. Porro, F.; Bockor, L.; De Caneva, A.; Bortolussi, G.; Muro, A.F. Generation of Ugt1-deficient murine liver cell lines using TALEN technology. PLoS ONE 2014, 9, e104816. [CrossRef]

161. Sung, P.S.; Murayama, A.; Kang, W.; Kim, M.S.; Yoon, S.K.; Fukasawa, M.; Kondoh, M.; Kim, J.S.; Kim, H.; Kato, T.; et al. Hepatitis C virus entry is impaired by claudin-1 downregulation in diacylglycerol acyltransferase-1-deficient cells. J. Virol. 2014, 88, 9233-9244. [CrossRef] [PubMed]

162. Deltcheva, E.; Chylinski, K.; Sharma, C.M.; Gonzales, K.; Chao, Y.; Pirzada, Z.A.; Eckert, M.R.; Vogel, J.; Charpentier, E. CRISPR RNA maturation by trans-encoded small RNA and host factor RNase III. Nature 2011, 471, 602-607. [CrossRef] [PubMed]

163. Cho, S.W.; Kim, S.; Kim, J.M.; Kim, J.S. Targeted genome engineering in human cells with the Cas9 RNA-guided endonuclease. Nat. Biotechnol. 2013, 31, 230-232. [CrossRef] [PubMed]

164. Cong, L.; Ran, F.A.; Cox, D.; Lin, S.; Barretto, R.; Habib, N.; Hsu, P.D.; Wu, X.; Jiang, W.; Marraffini, L.A.; et al. Multiplex genome engineering using CRISPR/Cas systems. Science 2013, 339, 819-823. [CrossRef]

165. Xiao, Y.; Luo, M.; Hayes, R.P.; Kim, J.; Ng, S.; Ding, F.; Liao, M.; Ke, A. Structure basis for directional R-loop formation and substrate handover mechanisms in type I CRISPR-Cas system. Cell 2017, 170, 48-60. [CrossRef]

166. Yin, H.; Xue, W.; Chen, S.; Bogorad, R.L.; Benedetti, E.; Grompe, M.; Koteliansky, V.; Sharp, P.A.; Jacks, T.; Anderson, D.G. Genome editing with Cas9 in adult mice corrects a disease mutation and phenotype. Nat. Biotechnol. 2014, 32, 551-553. [CrossRef] [PubMed]

167. Jarrett, K.E.; Lee, C.M.; Yeh, Y.H.; Hsu, R.H.; Gupta, R.; Zhang, M.; Rodriguez, P.J.; Lee, C.S.; Gillard, B.K.; Bissig, K.D.; et al. Somatic genome editing with CRISPR/Cas9 generates and corrects a metabolic disease. Sci. Rep. 2017, 7, 44624. [CrossRef]

168. Sin, Y.Y.; Price, P.R.; Ballantyne, L.L.; Funk, C.D. Proof-of-concept gene editing for the murine model of inducible arginase-1 deficiency. Sci. Rep. 2017, 7, 2585. [CrossRef]

169. Stephens, C.J.; Kashentseva, E.; Everett, W.; Kaliberova, L.; Curiel, D.T. Targeted in vivo knock-in of human alpha-1-antitrypsin cDNA using adenoviral delivery of CRISPR/Cas9. Gene Ther. 2018, 25, 139-156. [CrossRef] 
170. Estève, J.; Blouin, J.M.; Lalanne, M.; Azzi-Martin, L.; Dubus, P.; Bidet, A.; Harambat, J.; Llanas, B.; Moranvillier, I.; Bedel, A.; et al. Generation of induced pluripotent stem cells-derived hepatocyte-like cells for ex vivo gene therapy of primary hyperoxaluria type 1. Stem Cell Res. 2019, 38, 101467. [CrossRef] [PubMed]

171. Estève, J.; Blouin, J.M.; Lalanne, M.; Azzi-Martin, L.; Dubus, P.; Bidet, A.; Harambat, J.; Llanas, B.; Moranvillier, I.; Bedel, A.; et al. Targeted gene therapy in human-induced pluripotent stem cells from a patient with primary hyperoxaluria type 1 using CRISPR/Cas9 technology. Biochem. Biophys. Res. Commun. 2019, 517, 677-683. [CrossRef] [PubMed]

172. Zheng, Q.; Bai, L.; Zheng, S.; Liu, M.; Zhang, J.; Wang, T.; Xu, Z.; Chen, Y.; Li, J.; Duan, Z. Efficient inhibition of duck hepatitis B virus DNA by the CRISPR/Cas9 system. Mol. Med. Rep. 2017, 16, 7199-7204. [CrossRef] [PubMed]

173. Kostyushev, D.; Brezgin, S.; Kostyusheva, A.; Zarifyan, D.; Goptar, I.; Chulanov, V. Orthologous CRISPR/Cas9 systems for specific and efficient degradation of covalently closed circular DNA of hepatitis B virus. Cell. Mol. Life Sci. 2019, 76, 1779-1794. [CrossRef]

174. Liu, Y.; Zhao, M.; Gong, M.; Xu, Y.; Xie, C.; Deng, H.; Li, X.; Wu, H.; Wang, Z. Inhibition of hepatitis B virus replication via HBV DNA cleavage by Cas9 from Staphylococcus aureus. Antivir. Res. 2018, 152, 58-67. [CrossRef]

175. Haapaniemi, E.; Botla, S.; Persson, J.; Schmierer, B.; Taipale, J. CRISPR-Cas9 genome editing induces a p53-mediated DNA damage response. Nat. Med. 2018, 24, 927-930. [CrossRef]

176. Liu, Y.; Qi, X.; Zeng, Z.; Wang, L.; Wang, J.; Zhang, T.; Xu, Q.; Shen, C.; Zhou, G.; Yang, S.; et al. CRISPR/Cas9-mediated $p 53$ and Pten dual mutation accelerates hepatocarcinogenesis in adult hepatitis B virus transgenic mice. Sci. Rep. 2017, 7, 2796. [CrossRef]

177. Komor, A.C.; Kim, Y.B.; Packer, M.S.; Zuris, J.A.; Liu, D.R. Programmable editing of a target base in genomic DNA without double-stranded DNA cleavage. Nature 2016, 533, 420-424. [CrossRef]

178. Gaudelli, N.M.; Komor, A.C.; Rees, H.A.; Packer, M.S.; Badran, A.H.; Bryson, D.I.; Liu, D.R. Programmable base editing of $A \bullet T$ to $G \bullet C$ in genomic DNA without DNA cleavage. Nature 2017, 551, 464-471. [CrossRef]

179. Villiger, L.; Grisch-Chan, H.M.; Lindsay, H.; Ringnalda, F.; Pogliano, C.B.; Allegri, G.; Fingerhut, R.; Häberle, J.; Matos, J.; Robinson, M.D.; et al. Treatment of a metabolic liver disease by in vivo genome base editing in adult mice. Nat. Med. 2018, 24, 1519-1525. [CrossRef]

180. Anzalone, A.V.; Randolph, P.B.; Davis, J.R.; Sousa, A.A.; Koblan, L.W.; Levy, J.M.; Chen, P.J.; Wilson, C.; Newby, G.A.; Raguram, A.; et al. Search-and-replace genome editing without double-strand breaks or donor DNA. Nature 2019. [CrossRef]

181. Chung, S.J.; Fromme, J.C.; Verdine, G.L. Structure of human cytidine deaminase bound to a potent inhibitor. J. Med. Chem. 2005, 48, 658-660. [CrossRef] [PubMed]

182. Mol, C.D.; Arvai, A.S.; Sanderson, R.J.; Slupphaug, G.; Kavli, B.; Krokan, H.E.; Mosbaugh, D.W.; Tainer, J.A. Crystal structure of human uracil-DNA glycosylase in complex with a protein inhibitor: Protein mimicry of DNA. Cell 1995, 82, 701-708. [CrossRef]

183. Georgiadis, M.M.; Jessen, S.M.; Ogata, C.M.; Telesnitsky, A.; Goff, S.P.; Hendrickson, W.A. Mechanistic implications from the structure of a catalytic fragment of Moloney murine leukemia virus reverse transcriptase. Structure 1995, 3, 879-892. [CrossRef]

(C) 2020 by the authors. Licensee MDPI, Basel, Switzerland. This article is an open access article distributed under the terms and conditions of the Creative Commons Attribution (CC BY) license (http://creativecommons.org/licenses/by/4.0/). 